\title{
A PRÁTICA E A TEORIA: ESPINOSA CONTRA OS FILÓsOFOS *
}

Practice and the theory: Spinoza against the philosophers

\author{
Antônio David **
}

Resumo: O presente artigo procura analisar e qualificar a crítica de Espinosa aos filósofos e teólogos, feita no início do Tratado Político e em outros escritos. Para tanto, além do exame do campo semântico envolvido nas menções a ambos na sua obra, é dado destaque para o conceito de extorsio (extorsão). Este envolve um conteúdo ético, social e político, atingindo o âmago da dominação teológico-política.

Palavras-chave: Filosofia Teologia. Autoridade. Extorsão. Discrepância.

Abstract: This article aims to analyze and qualify Spinoza's criticisms of philosophers and theologians, undertaken at the beginning of Tractatus Politicus and in other works.. Besides examining the semantic field involving both categories in the author, the paper highlights the concept of extorsio (extorsion) which contains ethical, social, and political dimensions, at the heart of theologicalpolitical domination.

Keywords: Philosophy. Theology. Authority. Extortion. Discrepancy.

* Artigo recebido em 14/02/2020 e aprovado para publicação em 18/06/2020. Esse artigo é uma versão modificada do capítulo 1 da primeira parte de nossa tese de doutorado, que contou com financiamento do CNPq e da Capes (PDSE). Em relação às referências, ao lado da forma exigida pela revista, indicamos as siglas convencionadas entre os estudiosos da obra de Espinosa. No caso específico do Tratado Teológico-Político, o qual não é dividido em parágrafos e cujos capítulos são longos, indicamos a numeração da edição Gebhardt. Os trechos citados podem ter sofrido modificações de tradução em relação à edição consultada. Optamos por não traduzir os vocábulos imperium e civitas. Em relação aos vocábulos e expressões indicados entre colchetes em latim, optamos por mantê-los declinados, tal como se encontram no trecho citado.

** Doutor em filosofia pela USP. Professor da Escola de Comunicação e Artes da USP. 
Os filósofos concebem os afetos em nós conflitantes como vícios em que os homens incorrem por culpa própria. Por esse motivo, costumam rir-se deles, chorá-los, censurá-los ou (se querem parecer mais santos), detestá-los. Creem, assim, fazer uma coisa divina e atingir o cume da sabedoria quando aprendem a louvar de múltiplos modos uma natureza humana que não existe em parte alguma e a fustigar com sentenças aquela que realmente existe. Com efeito, concebem os homens não como são, mas como gostariam que fossem. De onde resulta que, as mais das vezes [plerumque], tenham escrito sátira em vez de ética, e que nunca tenham concebido política que possa ser posta à prova pelo uso [ad usum revocari], mas política que é tida por [haberetur] quimera ou que só poderia instituir-se [institui] na utopia ou naquele século de ouro dos poetas, onde sem dúvida não seria minimamente necessária. Como, por conseguinte, se crê [creditur] que em todas as ciências que têm uso [usum], é na política que a teoria é mais discrepante [discrepare] da prática [Praxi], considera-se [aestimantur] que não há ninguém menos idôneo [nulli minus idonei] para o governo de uma república do que os teóricos ou os filósofos ${ }^{1}$.

É com um duro ataque aos filósofos que Espinosa inicia o percurso demonstrativo do Tratado Político. Nessas linhas, note-se bem, Espinosa não se limita a afirmar apenas e tão somente não serem os filósofos idôneos para o governo de uma República; ele vai mais longe, afirmando não haver ninguém menos [nulli minus] idôneo para tanto. Qual é o sentido de um ataque tão extremo?

Ao leitor da obra de Espinosa, a refutação aos filósofos realizada nesse que é o último de seus escritos talvez cause estranheza. É verdade que essa passagem é muito semelhante ao que se encontra no Prefácio do livro III da Ética ${ }^{2}$, mas é igualmente certo que, não obstante sejam criticados no referido Prefácio, os filósofos não só não são alvo de semelhante ataque como, nele, a crítica é atenuada nas figuras dos "eminentíssimos homens" e de Descartes, a quem, supõe-se, Espinosa reconhece o mérito de não ter amaldiçoado nem ridicularizado os afetos humanos.

Tal atenuação encontra eco no conjunto da obra. Nos Pensamentos Metafísicos, nosso autor aponta a atenção que o filósofo tem em relação às leis

\footnotetext{
${ }^{1}$ ESPINOSA. Tratado Político. Tradução Diogo Pires Aurélio. São Paulo: Martins Fontes, 2009, I, §1, p. 5-6. O dicionário Gaffiot dá conta de que uma das possíveis traduções para o verbo revoco é "ramener a", no sentido de "juger d'après" ("julgar por"). Essa opção é remetida a um trecho de De Officiis, 3, 84, de Cícero ("cum ad veritatem coepi revocare rationem"). O Gaffiot informa ainda que o sentido do excerto de Cícero é confrontar a teoria com a prática. A expressão ad usum revocari na passagem do Tratado Político aqui citada aproxima-se dessa acepção.

${ }^{2}$ Idem. Ética. Tradução Grupo de Estudos Espinosanos; coordenação Marilena Chaui. São Paulo: Editora da Universidade de São Paulo, 2015, III, Pref., p. 233-5.
} 
da Natureza ${ }^{3}$, ao passo que, no Tratado Teológico-Político, sustenta que os filósofos, nada tendo senão luz natural, tentam compreender as coisas por conceitos claros e distintos, e que Salomão, superior a todos os seus contemporâneos pela luz natural, tenha feito mal e atuado de forma indigna a um filósofo por ter se entregue à sensualidade ${ }^{4}$. Na Ética, por seu turno, Espinosa sublinha a distância entre o gozo pelo qual é conduzido o ébrio e o gozo que o filósofo possui ${ }^{5}$. Por fim, tomando-se a correspondência, nosso autor refere-se aos filósofos como aqueles que estão "acima da lei, ou seja, aqueles que praticam a virtude, não como uma lei, senão por amor, porque isso é o mais excelente" ${ }^{\prime \prime}$.

A reverência aos filósofos não é maior que a reverência dispensada à filosofia, cujo objeto, segundo o Tratado Teológico-Político, "é unicamente a verdade"7, o que, na Ética, o levou a repreender àqueles que, partindo dos objetos dos sentidos, desrespeitam a "ordem do filosofar"

Ainda assim, poder-se-ia contra-argumentar dizendo que a refutação que abre o Tratado Político é focalizada: é da prática, em geral, e da política, em particular, que os filósofos seriam inaptos a falar e escrever. Mas sequer essa leitura parece crível. Não só porque na Ética Espinosa empenha-se em estabelecer o lugar da razão na condução da vida em comum, ao mesmo tempo em que fundamenta em bases filosóficas a gênese da sociedade e sua manutenção ${ }^{9}$, mas porque esse é o escopo por excelência também do Tratado Político. Ademais, não é de menor importância que o destinatário do Tratado Teológico-Político seja o "leitor filósofo"10, ainda que haja aqui um componente retórico, pois nesse tratado Espinosa toma para si a tarefa de separar a filosofia da fé ou da teologia para, com isso, defender a liberdade de filosofar no imperium ${ }^{11}$. Tais argumentos, contudo, poderiam ser economizados em benefício de um único, óbvio até, a saber, que o ataque aos filósofos é desferido na abertura de um tratado sobre a política escrito em bases filosóficas ${ }^{12}$.

Nesse sentido, a passagem soa ainda mais intrigante quando se leva em conta o fato de Espinosa assumir-se como filósofo e declarar conhecer nada

\footnotetext{
${ }^{3}$ Idem, Princípios de filosofia cartesiana e Pensamentos metafísicos. Tradução Homero Santiago e Luis César Guimarães Oliva. Belo Horizonte: Autêntica, 2015, II, XII, p. 259.

${ }^{4}$ Idem, Tratado Teológico-político. Tradução Diogo Pires Aurélio. São Paulo: Martins Fontes, 2003, II, G. 41, p. 46; VI, G. 88, p. 103; XIII, G. 167, p. 208.

${ }^{5}$ Idem, Ética, III, P 57, Esc., p. 333.

${ }^{6}$ Idem, Correspondencia completa, Ep. 19, p. 67.

${ }^{7}$ Idem, Tratado Teológico-Político, XIV, G. 179, p. 222.

${ }^{8}$ Idem, Ética, II, P 10, Esc. do Cor., p. 143.

${ }^{9}$ Idem, Ética, IV, P 35, Esc. do Cor. 2, p. 429; IV, P 37, Esc. 2, p. 435-9; IV, P 40, p. 443.

${ }^{10}$ Idem, Tratado Teológico-político, Pref., G. 12, p. 14.

${ }^{11}$ Idem, Ética, II, p. 49; XIV, p. 215.

12 Não por acaso, o capítulo II do Tratado Político consiste num resumo do Tratado Teológico-Político e da Ética.
} 
menos que a "verdadeira" filosofia", cuja estima o fez - à época vivendo de uma pensão que lhe fora oferecida por um amigo - declinar de um convite que lhe fora feito para lecionar na Universidade de Heidelberg: a despeito de, no convite, o professor de teologia Johannes Ludwig Fabritius garantir a Espinosa "uma vida digna de um filósofo [vitam Philosopho dignam]", Espinosa argumenta que, para dedicar-se à instrução dos jovens, teria com isso de abandonar sua "investigação filosófica"14.

De fato, quando se olha para o conjunto da obra, nas poucas passagens em que cita nominalmente esse ou aquele filósofo, em pelo menos duas ele o faz com reverência ${ }^{15}$, chegando mesmo em alguns momentos a colocar-se, explícita ou implicitamente, na posição de devedor de seu(s) pensamento(s), como ocorre, aliás, no Prefácio há pouco mencionado ${ }^{16}$.

Entre os comentadores de Espinosa, a questão tem sido debatida em duas frentes: de um lado, no estabelecimento de quem seriam os filósofos a que o parágrafo faz menção; de outro, na depreensão do sentido de conceitos e argumentos nele contidos, ou seja, no esforço de entender o que Espinosa quis dizer.

Em relação ao primeiro ponto, enquanto Balibar, Cristofolini, Campos e Fraenkel concordam que o alvo de Espinosa seriam Platão e o platonismo, para Chaui tratar-se-ia da teologia política ou, mais especificamente, da tradição escolástica da política ${ }^{17}$. Em sintonia com Chaui, Negri observa

\footnotetext{
${ }^{13}$ Idem, Correspondencia completa, Ep. 76, p. 188.

${ }^{14}$ Idem, Correspondencia completa, Ep. 47, 48, p. 137-8.

${ }^{15}$ Além de "celebérrimo" [celeberrimum], tal como figura no citado Prefácio, Descartes é também tido como "brilhantíssimo" [clarissimi] no Prefácio do livro V da Ética (Idem, Ética, V, Pref., p. 321). Por seu turno, Maquiavel é chamado de "agudíssimo" [acutissimus] em duas passagens do Tratado Político (Idem, Tratado Político, V, §7, p. 46; X, §1, p. 129). Embora tais adjetivações possam ser vistas como meras tópicas retóricas dos seiscentos - o que se nota, como de praxe, no tratamento dispensado por Espinosa aos correspondentes, em conformidade com a ars dictaminis -, ainda assim deve-se atentar para o fato de a reverência a Maquiavel e a Descartes, no corpo dos tratados, não ser necessária, mas uma opção do autor; basta dizer que, no curso da obra, em várias passagens mencionam-se filósofos sem que figure qualquer adjetivação.

${ }^{16}$ Muitos comentadores têm-se empenhado em discutir a recepção, em Espinosa, de autores ou correntes, desde o atomismo grego e dos estoicos, passando pela filosofia judaica medieval até filósofos modernos. De nossa parte, com base nas indicações que o próprio Espinosa dá, é possível afirmar, sem nenhuma dúvida, ser ele devedor de Euclides (ESPINOSA, Ética, II, P 40, Esc. 2, p. 201; Idem, Tratado Teológico-político, VII, G. 111, p. 131; Idem, Tratado da emenda do intelecto. Tradução Cristiano Novaes de Rezende. Campinas: Editora da Unicamp, 2015, \$24, p. 41; Idem, Correspondencia completa. Traducción, introducción, notas e índices Juan Domingo Sánchez Estop. Madrid: Hiperión, 1988, Ep. 56, p. 151).

${ }^{17}$ BALIBAR, E. Spinoza et la politique. Réimpression de la 3' édition. Paris: Presses Universitaires de France, 2005, p. 66-7; CRISTOFOLINI, P. "Spinoza e l'acutissimo fiorentino". In: Idem. Spinoza hedonista. Pisa: EDS, 2002, p. 25-40; CAMPOS, A. S. "Spinoza and the paradox of political freedom". Conatus. Vol. 8, no 16, dez. 2014, p. 20; Idem, Spinoza's Revolutions in Natural Law. New York: Palgrave Macmillan, 2012, p. 168; FRAENKEL, C. “Spinoza's philosophy of religion". In: DELLA ROCCA, M. (ed.). The Oxford Handbook of Spinoza. New York: Oxford University Press, 2018, p. 386; CHAUI, M. Política em Espinosa. São Paulo: Companhia das Letras, 2003, p. 156, 210.
} 
que o "alvo principal" de Espinosa seria a filosofia escolástica, ainda que considere que a crítica espinosana dirija-se à "filosofia em geral", salientando que nela estaria envolvida "toda a crítica seiscentista à utopia, de Hobbes a Descartes"18. Numa direção semelhante à adotada por Negri, não obstante reconheça que os filósofos visados por Espinosa seriam, "primeiro que tudo, os autores da Segunda Escolástica", Aurélio sustenta que, ao reportar-se aos filósofos, Espinosa teria feito menção a "diferentes grupos ou diferentes modos de encarar a política"19.

A posição de Negri e Aurélio ecoa o famoso artigo de Matheron, "Spinoza et la décomposition de la politique thomiste: machiavélisme et utopie", na qual esse intérprete sustenta que o escopo da passagem envolveria a "todos": ainda que por vias diversas, todos compartilhariam em algum momento de ideal normativo da política, em oposição a Espinosa ou à posição espinosana ${ }^{20}$. Assim como Matheron, para quem Espinosa teria repercutido certa "opinião pública" a respeito dos filósofos, para Aurélio a fonte de Espinosa teria sido o vulgo ou o senso comum ${ }^{21}$. Ainda na trilha aberta por Matheron, Tosel e Curley entendem que a crítica de Espinosa seria generalizante; mas, enquanto para Tosel o alvo de Espinosa seria "toda a tradição da filosofia prática", já Curley declara sua estranheza pela inclusão de Hobbes nesse universo ${ }^{22}$.

Como se vê, a localização exata do escopo não parece ser tranquila. Em meio às especulações generalizantes, houve até quem apostasse que, ao falar dos filósofos, Espinosa estaria se referindo aos "otimistas" 23 .

Em contrapartida, embora haja divergências quanto ao escopo do parágrafo, parece haver razoável convergência quanto ao sentido da passagem em questão. Quanto a isso, pensamos ser emblemático que uma parte

${ }^{18}$ NEGRI, A. The Savage Anomaly. The power of Spinoza's metaphysics and politics. Translation by Michael Hardt. Minneapolis: University of Minnesota Press, 1991, p. 186. Para um aprofundamento do ponto indicado por Negri, recomendamos JESUS, P. B. M. Sobre a elaboração de uma ciência das paixões em Descartes, Hobbes e Espinosa. Dissertação (Mestrado em Filosofia). Faculdade de Filosofia, Letras e Ciências Humanas. Universidade de São Paulo, 2015.

${ }^{19}$ AURÉLIO, D. P. Imaginação e poder. Estudo sobre a filosofia política de Espinosa. Lisboa: Edições Colibri, 2000, p. 38. Na sequência, Aurélio examina autores e obras em três subcategorias: teologia, utopia e teoria.

${ }^{20}$ MATHERON, A. Études sur Spinoza et les philosophies de l'âge classique. Lyon: ENS Éditions, 2011, p. 81. Mathéron verá a presença de Tomás de Aquino (como herança do aristotelismo) e de Morus (como herança do platonismo) nesse universo, ao qual inclui Hobbes (cf. especialmente p. 108-9).

${ }^{21}$ Idem. Études sur Spinoza et les philosophies de l'âge classique, p. 82, 93; AURÉLIO, D. P. Imaginação e poder. Estudo sobre a filosofia política de Espinosa, p. 38-9.

${ }^{22}$ TOSEL, A. Du matérialisme de Spinoza. Paris: Éditions Kimé, 1994, p. 105; CURLEY, E. "Kissinger, Spinoza, and Genghis Khan". In: GARRETT, D. (ed.). The Cambridge Companion to Spinoza. Cambridge University Press, 2006, p. 328-9.

${ }^{23}$ VARDOULAKIS, D. "Spinoza now: an introduction". In: Idem (ed.) Spinoza now. Minneapolis: The University of Minnesota, 2011, p. xi. 
dos comentadores apenas a cita, sem dar-se ao trabalho de interpretá-la, como se seu sentido fosse autoevidente ${ }^{24}$. Todavia, muitos procuraram ultrapassar a mera citação e buscar o sentido da crítica empreendida por Espinosa no trecho em questão. Aqui também, o estudo mais citado é o de Matheron, para quem a desconstrução da política normativa realizada por Espinosa teria como alvo, em todos os casos, e de maneira diferencial, a "condição de aplicabilidade" da norma. Para este autor, em que pesem as diferenças entre os filósofos da normatividade, o resultado de suas concepções políticas seria o mesmo: a inaplicabilidade ${ }^{25}$.

Ainda que adotando caminhos diferentes, a maior parte dos comentadores chegou a um resultado semelhante àquele obtido por Matheron. Assim, enquanto Chaui sustenta que a teologia, em Espinosa, "afasta a política de qualquer prática possível", e Aurélio assevera ser a ciência política tomista "impraticável" aos olhos de nosso autor ${ }^{26}$, já Kirste e Walther observam que, para nosso autor, os filósofos são, em geral, "descolados da realidade e, por conseguinte, politicamente ineptos" ${ }^{27}$. Na mesma direção, Campos entende que Espinosa crê que o conhecimento filosófico e científico dos governantes (rulers) seria "irrelevante para a produção de uma sociedade política bem sucedida" 28 . Por seu turno, Morfino argumenta que "Espinosa recusa a filosofia na medida em que ela produz uma política utópica", enquanto Visentini afirma que, em Espinosa, "o moralismo filosófico conduz a uma teoria política inutilizável" ${ }^{29}$. Em sintonia com essas leituras, Fraenkel argumenta que "expor o que pareceria o Estado ideal é um exercício fútil" na visão de Espinosa ${ }^{30}$.

Inaplicável, impraticável, irrealizável, inepta, irrelevante, utópica, inutilizável, fútil. Em que pesem os matizes que diferenciam as leituras dos

\footnotetext{
${ }^{24}$ Por exemplo: BALIBAR, E. Spinoza et la politique, p. 66-7; NEGRI, A. The Savage Anomaly. The power of Spinoza's metaphysics and politics, p. 186; CRISTOFOLINI, P. "Spinoza e l'acutissimo fiorentino", p. 25-40; CURLEY, E. "Kissinger, Spinoza, and Genghis Khan", p. 328-9; DEBRABANDER, F. Spinoza and the stoics. Power, Politics and the Passions. London: Continuum, 2007, p. 100; MORFINO, V. Le temps et l'occasion. La rencontre Spinoza-Machiavel. Paris: Classiques Garnier, 2012, p. 57-8; ROSENTHAL, M. A. "Spinoza's political phisosophy". In: DELLA ROCCA, M. (ed.). The Oxford Handbook of Spinoza. New York: Oxford University Press, 2018, p. 417. Para Curley, a posição de Espinosa seria "pragmática".

${ }^{25}$ MATHERON, A. Études sur Spinoza et les philosophies de l'âge classique, p. 92-5, 107-10.

${ }^{26}$ AURÉLIO, D. P. Imaginação e poder. Estudo sobre a filosofia política de Espinosa, p. 55-6.

${ }^{27}$ CHAUI, M. Política em Espinosa. São Paulo: Companhia das Letras, 2003, p. 128; KIRSTE, S.; WALTHER, M. "Political Philosophy as Theory of Practice (Chapter 1: Introduction)". In: BARTUCHAT, W., KIRSTE, S., WALTHER, M. (ed.). Naturalism and Democracy. A Commentary on Spinoza's Political Treatise in the Context of His System. Translated by James Fontini. Leiden; Boston: Brill, 2019, p. 12.

${ }^{28}$ CAMPOS, A. S. "Spinoza and the paradox of political freedom". Conatus. Vol. 8, no 16 , dez. 2014, p. 20.

${ }^{29}$ MORFINO, V. Le temps et l'occasion. La rencontre Spinoza-Machiavel, p. 13; VISENTIN, S. El movimiento de la democracia. Antropología y política em Spinoza. Tradución de Augustín Volco. Córdoba: Encuentro Grupo Editorial, 2011, p. 18.

${ }^{30}$ FRAENKEL, C. "Spinoza's philosophy of religion", p. 386.
} 
comentadores $^{31}$, todos parecem convergir para a mesma ideia - a qual coube a Tosel repetidamente vocalizar em seu trabalho ${ }^{32}$ : de que, aos olhos de Espinosa, a concepção de política dos filósofos carregaria o signo da impotência. Eis o que objetivamos colocar à prova em nossa investigação.

\section{O campo semântico da crítica à filosofia e à teologia}

Para além dos argumentos já elencados, vemos outra razão, mais forte, para dar crédito à hipótese de que de fato Espinosa considerava os filósofos os menos idôneos para o governo de uma República: porque negá-la levaria a jogar para debaixo do tapete todo um conjunto de menções a filósofos e teólogos no curso da obra, das quais o núcleo é a crítica da autoridade instituída e de seus efeitos sobre a vida comum.

Nosso ponto de partida será a não separação entre filosofia e teologia. Falamos de não separação ao invés de não subordinação da filosofia à teologia, como não raro é sublinhado pelos comentadores, pois de fato o alvo da crítica não são apenas aqueles que pretendem subordinar a filosofia à teologia, mas também aqueles que incorrem no erro contrário, isto é, os que almejam subordinar a teologia à filosofia. No Tratado Teológico-Político ${ }^{33}$, Espinosa sustenta que filosofia e teologia possuem, cada uma, seu próprio domínio [regnum]: o domínio da verdade e do saber (própria dos filósofos) e o domínio da piedade e da obediência (adequada ao comum dos homens), respectivamente ${ }^{34}$. A primeira opera com a certeza

\footnotetext{
${ }^{31}$ Vale mencionar que alguns comentadores veem a presença marcante de Maquiavel na crítica de Espinosa aos filósofos. NEGRI, A. The Savage Anomaly. The power of Spinoza's metaphysics and politics, p. 186-7; DEBRABANDER, F. Spinoza and the stoics. Power, Politics and the Passions, p. 100, 118; CURLEY, E. “Kissinger, Spinoza, and Genghis Khan", p. 328-9; MORFINO, V. Le temps et l'occasion. La rencontre Spinoza-Machiavel, p. 57-8. Matheron, no entanto, faz ressalvas quanto a essa leitura, distinguindo entre o maquiavelismo e o "autêntico Maquiavel": MATHERON, A. Études sur Spinoza et les philosophies de l'âge classique, p. 94, 100, 104, 111. Embora quase sempre indiquem o capítulo 15 d'O Príncipe, o paralelo com Maquiavel poderia ser evocado por um sutil ataque aos teóricos perpetrado no capítulo 3, quando Maquiavel coloca-se "contra todos os sábios" de seu próprio tempo (MAQUIAVEL, O Príncipe, Tradução Maria Júlia Goldwasser. São Paulo: Martins Fontes, 2001, p. 12). No entanto, afora o fato de essa posição sobrevalorizar a recepção de Maquiavel em Espinosa, ignorando o que os separa, ela sequer possui lastro histórico, ao menos não nas Sete Províncias do Norte. Sobre isso, cf. MULIER, E. H. "A controversial republican: Dutch views of Machiavelli in the seventeenth and eighteenth centuries". In: BOCK , G.; SKINNER, Q.; VIROLI, M. (ed.). Machiavelli and republicanism. Cambridge: Cambridge University Press, 1990, p. 263.

${ }^{32}$ TOSEL, A. Du matérialisme de Spinoza, p. 108s.

${ }^{33}$ Especificamente, no capítulo $\mathrm{XV}$, cujo título é: “Onde se demonstra que nem a teologia está a serviço da razão, nem a razão da teologia /.../" (ESPINOSA, Tratado Teológico-político, XV, G. 180, p. 223).

${ }^{34}$ Idem, Tratado Teológico-político, XV, G. 184, p. 228. A tese de que Deus se revelou aos profetas e aos homens de acordo com suas capacidades e opiniões, ou seja, de que as Escrituras foram escritas ao alcance do vulgo, é afirmada de maneira recorrente no Tratado Teológico-Político.
} 
do entendimento, enquanto a segunda opera com certezas morais $\mathrm{s}^{35}$. Entre uma e outra não só não há oposição como ambas conduzem ao mesmo lugar, a saber, a salvação (ou beatitude ou felicidade ou virtude) ${ }^{36}$. Em relação aos que procuram subordinar uma à outra, Espinosa é categórico:
É, todavia, claro, por aquilo que já dissemos, que tanto uns como os outros sustentam um erro crasso [toto coelo errare]. Com efeito, qualquer que seja dessas opiniões a que se adote, será sempre necessário adulterar [corrum- pere], ou a razão, ou a Escritura. Mostramos como a Escritura não ensina questões filosóficas, mas apenas a piedade, e como tudo o que nela se contém está adaptado à compreensão e às opiniões preconcebidas do vulgo. Quem, por conseguinte, a quiser adaptar à filosofia terá, com certeza, de atribuir aos profetas muitas coisas que eles nem por sonhos pensaram e de interpretar incorretamente seu pensamento. Quem, pelo contrário, faz da razão e da filosofia servas da teologia, terá de admitir como coisas divinas preconceitos populares de tempos antigos, deixando que estes o ceguem e lhe inundem a mente. Um com a razão, o outro sem ela, vão ambos, por certo, ensandecer [insaniet $]^{37}$.

A alusão ao ensandecimento nessa passagem não é pontual. A refutação empreendida por Espinosa a filósofos e teólogos quase sempre vem acompanhada de um vocabulário muito específico, o qual é, por isso mesmo, uma chave para a depreensão do sentido e do alcance da crítica espinosana à filosofia e à teologia.

Na Ética, lemos que "às vezes se vê homens serem afetados por um objeto de tal maneira que, embora não esteja presente, contudo creem tê-lo diante dos olhos", e que, quando isto acontece a um homem que não está dormindo, "dizemos que delira ou endoidece [delirare, vel insanire]"38. Nessa mesma direção, uma vez tendo sustentado que, se não tivessem experimentado que fazemos muitas coisas das quais depois nos arrependemos,

\footnotetext{
${ }^{35}$ Idem, Tratado Teológico-político, XV, G. 185s., p. 229s.

${ }^{36}$ Idem, Tratado Teológico-político, XV, Anotação XXXI, G. 188, p. 233.

${ }^{37}$ Idem, Tratado Teológico-político, XV, G. 180, p. 223-4. No que tange ao problema da separação entre filosofia e teologia, é elucidativa a troca epistolar entre Espinosa e Blyenbergh. Este, adotando duas regras para o filosofar, quais sejam, "o conceito claro e distinto do entendimento" e "a palavra revelada ou vontade de Deus", nomeia-se a si mesmo de "filósofo cristão". Em resposta a Blyenbergh, Espinosa argumenta: "não atribuo à Escritura essa verdade que o senhor crê existir nela e, no entanto, também estou convencido de que lhe atribuo tanta autoridade ou até mais do que o senhor". A autoridade da Escritura reside, para Espinosa, em seu domínio próprio. Na carta seguinte à resposta de Blyenbergh, na qual este lhe apresentara uma série de questões concernentes ao Tratado Teológico-Político, Espinosa informa a seu interlocutor que o considerava, na primeira carta, como "simples filósofo" [merum Philosophum] que "não tem outra pedra de toque para a verdade do que o entendimento natural e não a teologia (como concedem não poucos que se proclamam cristãos)", advertindo-o ainda que "quando falamos como filósofos, não devemos usar expressões da teologia" (Idem, Ep. 20, 21, 22, 23, p. 68-92).

${ }^{38}$ Idem, Ética, IV, P 54, Esc., p. 461. Na sequência desse trecho, Espinosa afirma ser a ambição uma espécie de delírio. No livro III, Espinosa afirmara o mesmo da soberba (Idem, Ética, III, P 26, Esc., p. 277). Voltaremos a ambas adiante.
} 
e que frequentemente, ao defrontarmo-nos com afetos contrários, vemos o melhor e seguimos o pior, nada os impediria de crer que tudo fazemos livremente, Espinosa argumenta, em alusão à maioria dos homens:

/.../ o bebê crê apetecer livremente o leite, o menino irritado, querer vingança, e o medroso, a fuga. Por sua vez, o embriagado crê falar por livre decreto da Mente aquilo que depois de sóbrio preferiria ter calado; assim o delirante [delirans], a tagarela [garrula], o menino [puer] e muitos outros de mesma farinha creem falar por livre decreto da Mente, quando na verdade não podem conter o ímpeto [impetu] que têm de falar, de tal maneira que a própria experiência, não menos claramente que a razão, ensina que os homens creem-se livres só por causa disto: são cônscios de suas ações e ignorantes das causas pelas quais são determinados ${ }^{39}$.

Já no Tratado Político, ao examinar a hipótese de que se poderia dizer que a civitas tem o direito ou o poder de ordenar as coisas que a natureza humana abomina, coisas a que ninguém pode ser induzido, nem com recompensas, nem com ameaças, nosso autor argumenta: "tal não pode conceber-se com nenhum outro sentido senão aquele em que se diria que o homem pode, por direito, enlouquecer e delirar" [insanire, $\mathcal{E}$ delirare] ${ }^{40}$.

Nesses termos, a crítica é dirigida aos homens em geral, não apenas aos filósofos. Essa abordagem é especialmente relevante nos Pensamentos Metafisicos, em que Espinosa ocupa-se explicitamente da linguagem dos filósofos: "porque o vulgo primeiramente encontra os vocábulos, que depois passam a ser usados pelos filósofos" ${ }^{41}$. Posto que as palavras "são uma parte da imaginação", "constituídas arbitrariamente conforme a compreensão do vulgo" e "causa de muitos grandes erros" ${ }^{\prime 2}$, nosso autor dirá na Ética não se admirar com o fato de que, "entre os Filósofos que quiseram explicar as coisas naturais só pelas imagens das coisas, tenham nascido tantas controvérsias" ${ }^{\prime 4}$.

Mas se nessas passagens acima o objeto da crítica são os homens em geral, quando se toma a obra de Espinosa de uma perspectiva de conjunto nota-se que o campo semântico aqui considerado é empregado, sobretudo, nas menções aos filósofos e teólogos.

Assim, no Tratado da Emenda do Intelecto, após examinar a maneira engenhosa como os filósofos teorizam sobre as ideias fictícias, Espinosa abre retoricamente sua crítica com as seguintes palavras: "Mas, deixando-os em seus delírios [deliriis], /.../"44; no Tratado Teológico-Político, nosso autor critica tudo aquilo que os teólogos "forjaram no seu delírio" [quicquid sic

\footnotetext{
${ }^{39}$ Idem, Ética, III, P 2, Esc., p. 245. Cf. também Idem, Correspondencia completa, Ep. 58, p. 154-6.

${ }^{40}$ Idem, Tratado Político, III, §8, p. 29.

${ }^{41}$ Idem, Pensamentos Metafísicos, I, VI, p. 215. Cf. ainda: I, I, p. 198-9; II, VI, p. 235; II, X, p. 247.

${ }^{42}$ Idem, Tratado da Emenda do Intelecto, §§88-9, p. 83.

${ }^{43}$ Idem, Ética, II, P 40, Esc. 1, p. 199.

${ }^{44}$ Idem, Tratado da Emenda do Intelecto, §61, p. 63.
} 
delirando fingunt $]^{45}$; na Ética, referindo-se implicitamente a Kepler, nota que "os objetos que movem os ouvidos são ditos produzir ruído, som ou harmonia, a qual enlouqueceu [dementavit] os homens a ponto de crerem que também Deus nela se deleita" ${ }^{\prime 6}$.

Tais passagens oferecem apenas uma parte do campo semântico com o qual Espinosa realiza o trabalho de refutação dos filósofos. No que tange à polêmica do movimento da terra em Josué 10, 12, após ter identificado as posições em litígio, Espinosa conclui: "Qualquer dessas interpretações me parece, evidentemente, ridícula [ridiculum]"47. O mesmo é dito daqueles que invocam a vontade de Deus sempre que não sabem explicar uma coisa: "Que maneira mais ridícula [ridiculus] de confessar a ignorância!" ${ }^{8}$.

Ao fazer referência à opinião da "maioria dos intérpretes" segunda a qual Deus manteve intacta toda a Bíblia e que as variantes são indício de mistérios, diz Espinosa: "Se o dizem por estúpida ou senil [stultitia et anili] devoção ou por arrogância ou malícia [arrogantia et malitia] /.../, não sei; o que eu sei é que nunca li nos seus livros algo que cheire a mistério, mas unicamente especulações infantis [pueriles]", e conclui: "Li também e conheci até pessoalmente alguns desses impostores e cabalistas, cuja [insanidade] [insaniam] nunca cheguei a admirar" ${ }^{\prime \prime 9}$.

Não é menos duro o tratamento dispensado a Maimônides, um dos alvos principais do Tratado Teológico-Político, paradigma daqueles que pretendem subordinar a teologia à filosofia ${ }^{50}$. Fazendo alusão a ele e a outros, Espinosa afirma estar "pura e simplesmente perante ficções [figmenta] sem base, nem na razão, nem na Escritura" ${ }^{51}$. Em outra passagem, na qual a Grande Sinagoga é motivo de exame, Maimônides e outros são acusados por Espinosa de forjar "uma invenção ridícula [ridiculum figmentum] e sem nenhum fundamento a não ser na tradição rabínica" 52. Finalmente, nosso autor o acusa - a ele e a outros - de "extorquir [extorquere] à Escritura as frivolidades [nugae] aristotélicas e as próprias invenções [figmenta]", do que conclui lhe parecer algo "sumamente ridículo [magis ridiculum]" 53 .

\footnotetext{
${ }^{45}$ Idem, Tratado Teológico-Político, VII, G. 98, p. 115.

${ }^{46}$ Idem, Ética, I, Ap., p. 119. Cf. KEPLER, J. Harmonies of the World. Translated by Charles Glenn Wallis, London, Toronto: Enciclopædia Britannica, 1952. (Great Books of the Western World, vol. 16), p. 1048.

${ }^{47}$ ESPINOSA, Tratado Teológico-Político, II, G. 36, p. 40.

${ }^{48}$ Idem, Tratado Teológico-Político, VI, G. 86, p. 101.

${ }^{49}$ Idem, Tratado Teológico-Político, IX, G. 135-6, p. 164.

${ }^{50}$ Espinosa argumenta ter sido Maimônides o primeiro dentre os fariseus que defendeu abertamente que se devia adaptar a Escritura à razão. Cf. Idem, Tratado Teológico-Político, XV, G. 181, p. 224.

${ }^{51}$ Idem, Tratado Teológico-Político, V, G. 80, p. 93.

${ }^{52}$ Idem, Tratado Teológico-Político, X, G. 150, p. 184.

${ }^{53}$ Idem, Tratado Teológico-Político, I, G. 19-20, p. 20-1. O conceito em questão, extorsio ("extorsão") é de fundamental importância para o que aqui almejamos mostrar e será examinado um pouco mais à frente.
} 
Nos Pensamentos Metafísicos, tratando das distinções que fazemos dos atributos de Deus, declara Espinosa pouco se importar com o "amontoado de distinções [distinctionum farraginem]" ${ }^{54}$ dos peripatéticos, e, poucas linhas depois, invocando a tese de Aristóteles das três almas, conclui tratar-se "apenas de ficções [figmenta]" 55 .

Mais contundente é o ataque à filosofia antiga grega no Tratado Teológico-Político. Após acusar de "[insana] soberba [superbe insanirent]" aqueles que rejeitam o entendimento, Espinosa admite nunca tê-los visto ensinar nada que não fosse as "especulações dos aristotélicos ou dos platônicos", para então concluir: "Não lhes bastasse já [ensandecer] [insanire] com os gregos, quiseram também que os profetas delirassem [deliravisse] com eles" ${ }^{\prime 56}$. No capítulo XVIII do mesmo tratado, ele volta a criticá-los, dizendo que, uma vez averiguados os ditos mistérios que se veem nas Escrituras, neles não se encontrará nada a não ser "[invenções] [commenta] de Aristóteles, de Platão ou de qualquer outro parecido", para concluir: " na maior parte dos casos, é mais fácil qualquer idiota [idiota] imaginá-las a sonhar que um grande erudito descobri-las a partir da Escritura" ${ }^{\prime 27}$.

Em face dos céticos, a crítica não é menos assertiva: sobre a persistência destes em manter-se em dúvida contra todas as evidências, Espinosa afirma tratar-se de "homens profundamente cegados [occæcatus] também no ânimo" ${ }^{58}$. Cegueira do ânimo, não do juízo, seja porque, no caso da dúvida autêntica, não temos o poder para suspender o juízo - afinal, "quando dizemos que alguém suspende o juízo nada dizemos senão que vê não perceber a coisa adequadamente", de modo que tal ato é "uma percepção [perceptio], não uma livre vontade [libera voluntas]" 59 -, seja porque, no caso da dúvida metódica, não se pode querer contra o que se sente, quando se o faz somente por palavras ${ }^{60}$.

Se Descartes, por seu turno, é reverenciado no Prefácio do livro III da Ética, nem por isso foi ele poupado de uma dura crítica, ainda que realizada de maneira bastante sutil, pelo emprego de uma expressão que costuma passar despercebido pelos comentadores. Segundo Espinosa, ao tentar explicar os afetos humanos por suas primeiras causas e, simultaneamente, mostrar a via pela qual a mente pode ter sobre eles imperium absoluto, Descartes não mostrou "nada além [nihil præter] que a agudeza de seu engenho"61. A expressão ultrapassa a mera retórica.

\footnotetext{
${ }^{54}$ Idem, Princípios de filosofia cartesiana e Pensamentos metafísicos, II, V, p. 235.

${ }^{55}$ Idem, Pensamentos Metafísicos, II, VI, p, 235.

${ }^{56}$ Idem, Tratado Teológico-Político, Pref., G. 9, p. 10.

${ }^{57}$ Idem, Tratado Teológico-Político, XIII, G. 168, p. 208.

${ }^{58}$ Idem, Tratado da Emenda do Intelecto, §47, p. 53.

${ }^{59}$ Idem, Ética, II, P 39, Esc., p. 225.

${ }^{60}$ Idem, Ética, II, P 39, Esc., p. 221.

${ }^{61}$ Idem, Ética, III, Pref., p. 235. À agudeza acrescente-se a "vã sutileza" (Idem, Pensamento Metafísicos, III, I, p. 207).
} 
Já no Prefácio do Livro V, Espinosa evidencia o contraste entre a intenção de Descartes de "nada deduzir senão de princípios conhecidos por si mesmos e nada afirmar senão aquilo que percebesse clara e distintamente" e o fato de ter ele adotado, ao discorrer sobre a união entre a mente e o corpo, "uma hipótese mais oculta que todas as qualidades ocultas [sumat omni occulta qualitate occultiorem]" - justamente ele que, ressalta Espinosa, "tantas vezes censurara os Escolásticos por terem querido explicar coisas obscuras por meio de qualidades ocultas" ${ }^{\prime 2}$.

Se a crítica a Descartes é realizada, por assim dizer, com palavras mais suaves do que aquelas que são empregadas para com outros, já os cartesianos contemporâneos de Espinosa nos Países Baixos não tiveram sorte melhor sob sua pena, porém não em razão de suas ideias: com medo de que fossem confundidos com Espinosa e com vistas a remover tal suspeição, passaram a denunciá-lo, motivo pelo qual nosso autor lhes chama de "estúpidos [stolidi]"63.

Particularmente interessante para o exame aqui proposto é a correspondência entre Espinosa e Boxel ${ }^{64}$. A troca de cartas é iniciada por esse último, interessado que estava em saber a opinião de nosso autor sobre a aparição (existência) de espectros ou lêmures. Repleta da semântica aqui destacada, a polêmica é de especial relevo para nós ainda por outro motivo: ela desemboca no problema da autoridade.

Provocado pela indagação, Espinosa inicia sua resposta com uma aparente concessão, informando que se "os filósofos" querem chamar espectros coisas que ignoramos, não os contrariará, pois infinitas são as que a ele escapam. Na sequência, todavia, Espinosa refuta a existência de semelhantes entes, valendo-se para isso do mesmo argumento que figura nas primeiras linhas do Tratado Político: "aquele desejo que os homens comumente têm de narrar as coisas não como elas são realmente, mas como as desejam, conhece-se mais facilmente a partir de narrativas sobre lêmures e espectros que doutras". Ao final, nosso autor enquadra tais coisas no universo das ideias fictícias: "forja-as [fingit], porém, especialmente para justificar o medo que concebeu de sonhos e fantasmas, ou ainda, para reforçar sua audácia, fé e opinião" ${ }^{65}$.

As considerações feitas por Boxel em sua resposta a Espinosa não poderiam ser mais instigantes. Este é incitado a posicionar-se diante de autoridades. Como na primeira missiva, também nessa insiste seu amigo na indagação inicial, mas agora Boxel o faz através do argumento de homens eruditos:

\footnotetext{
${ }^{62}$ Idem, Ética, V, Pref., p. 521.

${ }^{63}$ Idem, Correspondencia completa, Ep. 68, p. 177.

${ }^{64}$ Idem, "Epístolas: Espinosa e Boxel". Apresentação, preparação do texto latino, tradução e notas Samuel Thimounier. Revisão técnica Homero Santiago. Cadernos Espinosanos, n ${ }^{\circ} 35$, jul.-dez. 2016, Ep. 51 a 56, p. 523-71.

${ }^{65}$ Idem, “Epístolas: Espinosa e Boxel”, Ep. 51, p. 533.
} 
médicos, historiadores, matemáticos, teólogos e filósofos. Ao final da carta, Boxel introduz uma nota, afirmando nela que, à indagação antes feita por Espinosa, "sobre estultos e loucos [stultis, et amentibus]", ele a responde citando Lavater, para quem "seria imprudência insigne contradizer, temerária e impudentemente, tantos fidedignos historiadores, padres e outros dotados de grande autoridade [magna autoritate]"66.

Em sua resposta, Espinosa recrudesce: "todos eles deliram do mesmo modo [omnes eodem modo delirare] e amam histórias de coisas incomuns, que deixam atônitos os homens e os arrebatam em admiração". Tendo exposto seus argumentos ao longo da carta, ao final confessa ter "espantado[-se] muito, não com as histórias que são narradas, mas com aqueles que as escrevem", e declara: “admira-me que homens dotados de engenho e juízo empreguem sua eloquência e abusem dela para que nos persuadam de frivolidades [nugae] desse tipo" ${ }^{\prime \prime 7}$.

A continuação da correspondência é marcada por uma inflexão, em que não é mais o argumento dos filósofos que é posto em questão, mas sua autoridade. Segundo Boxel, "todos [omnes] os filósofos, tanto antigos quanto modernos, se julgam convictos de que espíritos se dão", do que conclui, atônito, que Espinosa os coloca no mesmo saco do "vulgo":

Rejeita, então, tantas sábias testemunhas oculares e auriculares, tantos filósofos, tantos historiadores que narram tais coisas; afirma que todos eles são, com o vulgo, estultos e insanos [stultos, ac insanos], ainda que tuas respostas não persuadam, mas sejam, na verdade, absurdas e em nenhuma parte toquem o escopo de nossa controvérsia, e que, de fato, tu não profiras prova alguma que confirme tua opinião $0^{68}$.

Ao evocar o argumento de que seu interlocutor deveria provar a não existência de espectros e lêmures, Boxel introduz um impasse no debate em curso. Isso porque, da perspectiva de Espinosa, não se pode provar a não existência de algo, mas sua existência: "dificilmente coligimos de alguma história que se dão espectros; colige-se sim que são algo que, contudo, ninguém sabe o que é" ${ }^{\prime \prime 9}$. O ônus da prova caberia não a Espinosa, mas a seus adversários. E, embora Boxel evoque a experiência em seu argumento ${ }^{70}, \mathrm{o}$ fato é que ele não se refere à experiência, mas ao testemunho de outros, ou seja, ao argumento de autoridade ${ }^{71}$.

\footnotetext{
${ }^{66}$ Idem, "Epístolas: Espinosa e Boxel", Ep. 53, p. 541.

${ }^{67}$ Idem, "Epístolas: Espinosa e Boxel", Ep. 54, p. 543.

${ }^{68}$ Idem, "Epístolas: Espinosa e Boxel", Ep. 55, p. 561.

${ }^{69}$ Idem, "Epístolas: Espinosa e Boxel", Ep. 52, p. 533, o destaque é nosso.

${ }^{70}$ Idem, "Epístolas: Espinosa e Boxel", Ep. 53, p. 539-41.

${ }^{71}$ No Tratado da Emenda do Intelecto, Espinosa estabelece os quatro principais modos de perceber [modos percipiendi], dos quais a percepção "por ouvir" [ex auditu] é o primeiro e a "experiência vaga" [experientia vaga], o segundo. Pouco antes, ao apresentá-los, ele os definira como modos de perceber para afirmar ou negar algo "independentemente de dúvidas" [indubie] (Idem, Tratado da Emenda do Intelecto, \$\$18-9, p. 37).
} 
Em contrapartida, diz Espinosa: "/.../ é certo que, sobre uma coisa que a experiência mostra tão claramente, devemos saber o que é"772. Todavia, espectros e lêmures não oferecem suas essências objetivas ${ }^{73}$, ou uma ideia clara e distinta de si, suficientes para que se tire toda a dúvida sobre sua existência ${ }^{74}$. Não se podendo provar a existência desses entes, Espinosa não pode considerá-las de outra maneira senão como sonhos que discre-

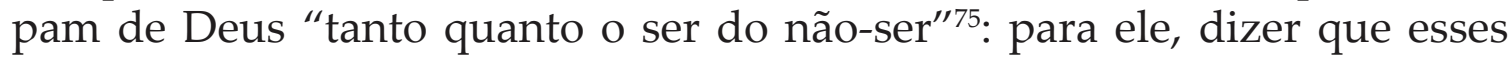
entes são invisíveis vale tanto como se Boxel dissesse "o que não são, e não o que são"76.

Antes de prosseguirmos, convém dedicar ainda algumas linhas ao desfecho da troca epistolar entre Espinosa e Boxel. Segundo Espinosa, a atenção [attentio] que exigira de seu interlocutor não foi vista por ele como necessária, razão pela qual Boxel não teria fixado [defixeris] seus pensamentos no principal, mas negligenciado maximamente aquilo que era útil ao assunto $^{77}$. Com isso, e constatando que seu interlocutor não parte dos mesmos princípios que ele, Espinosa encerra a discussão, sem, contudo, deixar de posicionar-se diante do argumento segundo o qual a grande quantidade de escritos e/ou testemunhos de eminentes autoridades seria válido como prova:
/.../ muitos foram os que tiveram tanto empenho em contradizer que ridicularizaram até mesmo demonstrações geométricas. Sexto Empírico e outros céticos que citas dizem ser falso que o todo é maior que sua parte, e julgam assim sobre os demais axiomas. /.../ A autoridade de Platão, Aristóteles e Sócrates não vale muito para mim [Non multum apud me Authoritas Platonis, Aristotelis, ac Socratis valet]. Teria me admirado se tivesses citado Epicuro, Demócrito, Lu-

\footnotetext{
${ }^{72}$ Idem, "Epístolas: Espinosa e Boxel", Ep. 52, p. 533, o destaque é nosso.

${ }^{73}$ Segundo Espinosa, "a verdade não exige signo algum, mas é suficiente ter as essências objetivas das coisas ou, o que é o mesmo, as ideias, para que se elimine toda a dúvida" (Idem, Tratado da Emenda do Intelecto, §36, p. 47). Nos seiscentos, a essência objetiva [essentia objectiva] designa a ideia da coisa, ao passo que a essência formal [essentia formalis] designa a coisa mesma. A partir da filosofia kantiana, o sentido desses termos mudará.

${ }^{74}$ Leve-se em conta que "a dúvida nada mais é que a suspensão da alma no atinente a alguma afirmação ou negação, que afirmaria ou negaria se não ocorresse algo que, desconhecido, deixa imperfeito o conhecimento dessa coisa" (Idem, Tratado da Emenda do Intelecto, §80, p. 77). Em relação a espectros e lêmures, não pode haver verdadeiramente dúvida porque, no caso, a alma nada afirmaria ou negaria. Não sendo verdadeiramente uma dúvida, como caracterizar os questionamentos de Boxel? No Tratado da Emenda do Intelecto, Espinosa se refere à teimosia (pertinaciæ) daqueles que dizem com palavras que duvidam, embora não duvIdem interiormente (Idem, Tratado da Emenda do Intelecto,, §77, p. 75).

${ }^{75}$ Idem, "Epístolas: Espinosa e Boxel", Ep. 54, p. 549.

${ }^{76}$ Idem, "Epístolas: Espinosa e Boxel", Ep. 56, p. 569.

77 A pouca atenção de Boxel e sua negligência parece ser um caso concreto da tese segundo a qual "/.../ quanto menos a mente intelige e, no entanto, percebe muitas coisas, tanto maior potência tem para forjar [fingendi]; e quanto mais intelige, tanto mais aquela potência é diminuída" (Idem, Tratado da Emenda do Intelecto, p. §58, p. 61).
} 
crécio ou algum dos atomistas e defensores dos átomos; com efeito, não é de admirar que aqueles que inventaram [commenti sunt] as qualidades ocultas, espécies intencionais, formas substanciais e outras mil frivolidades [nugas], tenham excogitado espectros e lêmures e crido em velhinhas a fim de diminuir a autoridade [authoritatem] de Demócrito, cuja boa fama invejaram tanto que queimaram todos os livros dele, que com tanto louvor ele publicara. Se há ânimo para lhes dar fé [fidem adhibere], que razões tens para negar os milagres da Virgem Divina e de todos os santos, que são listados por tantos filósofos, teólogos e historiadores celebérrimos, que destes posso reproduzir até mesmo cem, mas daqueles, dificilmente um? ${ }^{78}$

Na carta anterior, Espinosa já havia advertido Boxel sobre a estima deste às autoridades "mais do que merecem"79. Agora, porém, Espinosa é mais assertivo, desferindo um ataque em vários âmbitos: no campo epistemológico, ataca-se a invenção; no campo ético, ataca-se a obstinação (céticos) e a inveja (Platão); no campo político, ataca-se a censura e a oposição à liberdade de pensamento e de expressão (na figura da queima de livros); no campo social, ataca-se o louvor da alta celebridade; no conjunto, ataca-se o louvor àquilo que possui mais adeptos ou, caso queira, do vulgar ("destes posso reproduzir até mesmo cem, mas daqueles, dificilmente um"). O corolário dessa composição é a superstição. Não por acaso, a crítica realizada no Tratado Teológico-Político, cujo alvo por excelência é a superstição, tem de dar conta dessas quatro dimensões da autoridade.

A correspondência com Boxel figura como paradigmática da crítica aos filósofos e teólogos porque, partindo de problemas ligados ao conhecimento para os quais a semântica da loucura é mobilizada, em seu desenrolar chegou-se ao âmago do problema: a autoridade. Será a circulação do Tratado Teológico-Político a partir dos anos 1670 que a converterá em foco da polêmica entre Espinosa e seus interlocutores ${ }^{80}$. É o que abordaremos nas linhas a seguir.

\footnotetext{
${ }^{78}$ Idem, "Epístolas: Espinosa e Boxel", Ep. 56, p. 569. "A Inveja é o Ódio enquanto afeta o homem de tal maneira que se entristece com a felicidade do outro e, inversamente, regozija-se com o mal do outro" (Idem, Ética, III, Def. dos Afetos 23, p. 351).

${ }^{79}$ Idem, "Epístolas: Espinosa e Boxel", Ep. 54, p. 571. "A Superestima é, por Amor, estimar outrem além da medida" (Idem, Ética, III, Def. dos Afetos 21, p. 349).

${ }^{80}$ Em carta a Oldenburg escrita entre setembro e outubro de 1665, Espinosa confidencia-lhe estar escrevendo um tratado no qual pretende expor suas opiniões sobre a Escritura - trata-se do Tratado Teológico-Político -, e oferece três razões para tanto: "1. os preconceitos dos teólogos; pois sei que eles impedem maximamente que os homens possam aplicar o ânimo à filosofia; azafamo-me, pois, em explicá-los e afastá-los das mentes dos mais prudentes; 2. a opinião que de mim tem o vulgo, que não cessa de insimular-me de ateísmo, forço-me o quanto possível a também afastá-la; 3. a liberdade de filosofar e dizer as coisas que pensamos, a qual desejo asserir de todos os modos, e que aqui é suprimida de qualquer maneira por causa da demasiada autoridade e petulância [nimiam authoritatem, et petulantiam] dos pregadores" [Idem, "Correspondência entre Espinosa e Oldenburg". In: FERREIRA,
} 
Antes, porém, de concluir essa parte, não podemos deixar de tocar na relação entre Espinosa e Hobbes e, a partir dela, tratar, de uma maneira global, da estratégia de citação realizada por Espinosa. Na obra de Espinosa, não obstante Hobbes figure como um interlocutor de primeira ordem, há apenas duas explícitas ao filósofo inglês ${ }^{81}$. Nelas, não há adjetivos elogiosos, mas tampouco as menções vêm acompanhadas de palavras depreciativas. Nossa hipótese é que Espinosa reconhece a contribuição ímpar de Hobbes à modernidade filosófica, o que pode ser estendido a Descartes, em especial porque ambos procuraram entender e explicar os afetos humanos. Em última instância, pode-se dizer que Espinosa é um hobbesiano e um cartesiano no sentido muito específico de que sua filosofia só foi possível a partir das filosofias destes que o precederam. Ainda assim, quando se leva em conta os resultados teóricos e os desdobramentos práticos de suas filosofias, mais que a proximidade, julgamos ser merecedora de destaque a distância entre Espinosa e ambos ${ }^{82}$.

$\mathrm{O}$ fato de Hobbes não ter sido nominalmente mencionado no Tratado Político quando a interlocução com ele é marcante nessa obra - o que se pode dizer também de Grotius ${ }^{83}$-, é emblemático da estratégia de Espinosa quanto à citação de autores, obras ou correntes de pensamento, cujas ocorrências são em geral poucas na obra. Vemos três razões para a parcimônia de Espinosa no uso de referências explícitas: em primeiro lugar, sendo a crítica dirigida às ideias em si, não a quem as sustentou, objetiva-se reter a atenção do leitor aos argumentos em si mesmos; em segundo lugar, procura-se evitar o estigma, o que é mais que compreensível em se tratando de uma obra que confronta todos os cânones da tradição em suas várias vertentes; em terceiro lugar, e como procuramos mostrar, tem-se em vista acentuar o poder da crítica quando esta finalmente é realizada de maneira explícita e nominal.

O risco envolvido no emprego de referências está em fina sintonia com o argumento que se encontra nos Pensamentos Metafísicos segundo o qual

\footnotetext{
S. T. A correspondência entre Espinosa e Henry Oldenburg. Dissertação (Mestrado em Filosofia). Faculdade de Filosofia, Letras e Ciências Humanas. Universidade de São Paulo, 2019, Ep. 30, p. 167]. Já em 1675, Burgh escreverá a Espinosa, a propósito do Tratado Teológico-Político: "afora seus discípulos, todos os demais filósofos estão em desacordo com você" (Idem, Correspondencia completa, Ep. 67, p. 165).

${ }^{81}$ Em carta datada de 1674, Espinosa responde a Jelles: “Tu me perguntas qual é a diferença entre a concepção política de Hobbes e a minha. Respondo-te: a diferença consiste em que mantenho sempre o direito natural" (Idem, Correspondencia completa, Ep. 50, p. 139). Na sequência, nosso autor informa que, em qualquer cidade [urbe], o magistrado supremo só tem direitos sobre os súditos na medida em que seu poder seja superior ao deles, coisa que sempre ocorre no estado natural. Por sua vez, no Tratado Teológico-Político, Espinosa argumenta que “a razão, em todas as circunstâncias, aconselha a paz, e a paz só pode ser conseguida se o direito público do imperium se mantiver inviolado", e, entre parênteses, assevera: "Hobbes é de opinião diferente" (Idem, Tratado Teológico-Político, XVI, Anotação XXXIII, G. 195, p. 241). ${ }^{82}$ Cf. JESUS, P. B. M. Sobre a elaboração de uma ciência das paixões em Descartes, Hobbes e Espinosa.

${ }^{83}$ Tome-se, por exemplo, as notas de Ramond à margem do texto latino.
} 
determinados erros cometidos pelos filósofos "verbalistas e gramaticistas" advêm do fato de estes julgarem "as coisas pelos nomes, e não os nomes pelas coisas" 84 . Espinosa tem a pretensão de que os filósofos - seus adversários e ele próprio - julguem e sejam julgados pelos argumentos que sustentam, não o inverso ${ }^{85}$. E se sua estratégia foi quase sempre omitir o nome de seus interlocutores, a troca epistolar parece dar razão a Espinosa: pois, como é recorrente nas cartas, para muitos o nome é por si mesmo fonte de autoridade e, como tal, coage o julgamento acerca dos argumentos ${ }^{86}$.

Em face do que aqui expusemos, é prudente a ressalva de que, na obra de Espinosa, nem todos os filósofos e teólogos são tidos por delirantes: nas linhas acima, destacamos a presença marcante de Euclides na filosofia de Espinosa, mostramos que também os atomistas mereceram o apreço de nosso autor e, ainda que de maneira muito superficial, chamamos a atenção para certos laços que o unem a Maquiavel. Certamente há muitos teóricos que mereceriam o apreço de Espinosa, o que se expressa na própria troca epistolar e no círculo de Espinosa ${ }^{87}$. Nada disso, no entanto, pode servir para escamotear o fato de que, nas menções a filósofos e teólogos realizadas ao longo da obra, não só há um claro predomínio pela refutação, como esta se dá através da semântica aqui observada.

Insania, dementia (insanidade, ensandecimento, loucura, demência), delirium (delírio), stultitia (estupidez), cæcitas (cegueira), nuga (frivolidade), puerilitas (infantilidade), anilitas (senilidade), ridiculus (ridículo). Presença marcante nas passagens acima examinadas, em que o acerto de contas com a tradição é direto, o vocabulário opera como marca da refutação aos filósofos e teólogos. Poupado dessa plêiade, quase sempre ao comum

\footnotetext{
${ }^{84}$ Idem, Pensamentos Metafísicos, I, I, p. 199.

${ }^{85}$ Sobre a interlocução entre filósofos e o tornar-se filósofo, Espinosa defende que ambas em nada envolvem autoridade ou obediência: "porque, se os homens que escutam os profetas se tornassem profetas, como se tornam filósofos os que ouvem os filósofos, então o profeta não seria um intérprete dos decretos divinos, pois seus ouvintes não se apoiariam no testemunho $e$ autoridade do próprio profeta, mas sim na revelação divina e no testemunho interior" (Idem, Tratado Teológico-Político, I, Anotação II, G. 16, p. 15, o destaque é nosso).

${ }^{86}$ Além de confrontar a excessiva autoridade que parte de seus correspondentes atribuem aos filósofos, nas cartas Espinosa demonstra preocupar-se com os rumores em relação a seu próprio nome. É emblemática a passagem do Tratado Teológico-Político na qual, identificando a si mesmo e a seus discípulos como "filósofos", ele argumenta: "porque as coisas, infelizmente, chegaram a um ponto em que até homens que confessam abertamente não ter a mínima ideia de Deus nem o conhecer senão pelas coisas criadas (das quais ignoram as causas) não se envergonham de acusar de ateísmo os filósofos" (Idem, Tratado Teológico-Político, II, G. 30, p. 33). Como é sobejamente conhecido, a circulação do tratado agravou o estigma de Espinosa. Prova disso é o pedido feito por ele a seu amigo Jarig Jelles para que impedisse a tradução desta obra para o holandês (Idem, "Carta 44". Tradução, introdução e notas Antônio David. Cadernos de Ética e Filosofia Política, no 20, p. 178-81). Voltaremos à questão da perseguição a Espinosa adiante. Para uma leitura diversa desta que apresentamos no corpo do artigo, mas não oposta a ela, cf. AKKERMAN apud AURÉLIO, D. P. Imaginação e poder. Estudo sobre a filosofia política de Espinosa, p. 49-50.

${ }^{87}$ MEINSMA, K. O. Spinoza et son cercle. $2^{\text {ème }}$ édition. Paris: Vrin, 1984.
} 
dos homens Espinosa atribui simplesmente a ignorantia (ignorância) ${ }^{88}$. Há uma boa razão para isso.

\section{O conceito de extorsio e a autoridade teológico- politica}

Empregado nos seiscentos pelos eruditos, o campo semântico aqui destacado segue, de um lado, a tradição médica greco-latina e, de outro, a arte retórica latina ${ }^{89}$. Entretanto, porque seu emprego na obra é quase sempre acompanhado do emprego de outras duas palavras, quais sejam, figmentum (ficção) e commentum (invenção), ele ganha novo sentido na obra de Espinosa. Nela, a crítica se realiza não no campo dos males do corpo, ou daquilo que falta à saúde (tradição médica), nem no campo do juízo e da agudeza de engenho, ou daquilo que falta ao decoro (tradição retórica), mas no campo da imaginação e da vida afetiva, no qual não há falta, carência ou privação ${ }^{90}$.

Para que se depreenda esse ponto e para que dela se extraia conclusões e hipóteses de interesse no campo dos estudos espinosanos, devemos começar por uma breve incursão pela teoria do conhecimento em Espinosa.

Toda ideia simples é forçosamente verdadeira, porque, sendo simples, ela nos é dada por inteiro: "se a ideia é de alguma coisa simplíssima, ela não poderá ser senão clara e distinta; pois essa coisa não poderá dar-se em parte, mas tudo ou nada dela"191. A ideia fictícia nasce da composição confusa de ideias: "que são de diversas coisas e ações existentes na Natureza, ou melhor, provêm da atenção simultânea, mas sem assentimento [sine assensu], a tais ideias diversas" ${ }^{\prime \prime 2}$.

\footnotetext{
${ }^{88}$ Sobre a distinção entre o comum dos homens e o filósofo, cf. DAVID, A. "O vulgo e a interpretação da obra de Espinosa". Cadernos Espinosanos. São Paulo, no 39, jul.-dez. 2018.

${ }^{89}$ HANSEN , J. A. A sátira e o engenho: Gregório de Matos e a Bahia do século XVII. São Paulo: Ateliê Editorial; Campinas: Editora da Unicamp, 2004; JOUANNA , J. Greek medicine from Hippocrates to Galen: selected papers by Jacques Jouanna; edited with a preface by Philip van der Eijk, translated by Neil Allies. Leiden; Boston: Brill, 2012.

${ }^{90}$ Não é ocasional o fato de Espinosa introduzir, logo na primeira resposta a Boxel a fim de refutar a existência de espectros e lêmures, a noção de figmentum (ficção). Se a existência desses entes não pode ser provada, sua ideia, contudo, existe, e, assim sendo, cabe mostrar a natureza dessa ideia; enquanto tal, ela é algo de afirmativo porque denota a potência de imaginar da mente. Sobre esse ponto, cf. CHAUI , M. A nervura do real. Imanência e liberdade em Espinosa (Vol. 2 - Liberdade). São Paulo : Companhia das Letras, 2016.

${ }_{91}$ ESPINOSA, Tratado da Emenda do Intelecto, §63, p. 65.

${ }^{92} \mathrm{Na}$ sequência, Espinosa oferece um exemplo: “Por exemplo: depois que conhecemos a natureza do círculo e também a do quadrado, já não podemos compor essas duas e fazer um círculo quadrado, ou uma alma quadrada, e coisas semelhantes" (Idem, Tratado da Emenda do Intelecto, §64, p. 377).
} 
A noção de assentimento é chave para o nosso propósito. Recebido dos estoicos por Descartes, nele o assentimento designa a livre faculdade da vontade para formar juízos acerca do que percebemos. Em Espinosa, para quem a vontade não é livre, posto ser uma imagem das volições e do apetite, o termo é empregado no bojo da crítica à filosofia cartesiana para designar afirmação ou negação $0^{93}$. Com isso, o que nas ideias fictícias não tem o assentimento - isto é, não é afirmado nem negado - são as ideias simples, posto que tomadas de maneira indistinta ${ }^{94}$.

Particularmente importante é o fato de, na ideia fictícia, serem oferecidas causas pelas quais se pode inferir que as representações não vêm das coisas de fora, o que não se dá com a ideia falsa: "enquanto as representações se oferecem a alguém, não se oferecem quaisquer causas pelas quais, como era o caso do forjador, ele possa coligir que elas não se originam das coisas fora dele", o que, completa Espinosa "quase não é senão sonhar de olhos abertos, ou seja, enquanto estamos em vigília" ${ }^{\prime 5}$. Nestes termos, não assentir significa abster-se de afirmar ou negar as causas que são oferecidas pela experiência e que conduziriam a concluir que a ideia é fictícia.

Portanto, se a ficção nasce da indistinção, a via pelo qual podemos evitá-las é dada pela distinção entre as ideias que compõem a ideia fictícia. Noutros termos, "quanto mais geralmente se concebe a existência, tanto mais confusamente ela é concebida, e mais facilmente pode ser forjada em qualquer coisa", mas "quando é concebida particularmente, mais claramente, então, é entendida, e mais dificilmente é forjada em algo a não ser na própria coisa, quando não atentamos à ordem da Natureza" ${ }^{\prime \prime 6}$. Mais à frente abordaremos os desdobramentos práticos dessa ideia, que são de grande importância ${ }^{97}$.

Tais considerações em torno da ideia fictícia, amparadas no Tratado da Emenda do Intelecto, permanecem contudo incompletas se observadas à parte de outras passagens da obra, em particular do Tratado Teológico-Político:

\footnotetext{
93 "/.../ uma faculdade de assentir, ou seja, de afirmar ou de negar /.../" [assentiendi, sive affirmandi, E negandi facultare] (Idem, Ética, II, P 49, Esc., p. 221).

${ }_{94}$ Idem, Tratado da Emenda do Intelecto, §63, p. 65.

${ }_{95}$ Idem, Tratado da Emenda do Intelecto, §66, p. 67.

${ }^{96}$ Idem, Tratado da Emenda do Intelecto, $\S \S 55,58$, p. 57, 61.

${ }^{97}$ É bastante interessante - e promissor como horizonte de pesquisa - o parentesco entre Espinosa e Maquiavel quanto a esse ponto. Para Maquiavel, se o comum dos homens, voltado para as aparências, "nutre-se tanto do que parece ser quanto do que é", e se "muitas vezes se [comove] mais com as coisas que parecem ser do que com as que são" (MAQUIAVEL, N. Discursos sobre a primeira década de Tito Lívio. Tradução MF. São Paulo: Martins Fontes, 2007, p. 87-8), é igualmente certo, em compensação, que "os homens se enganam muito nas coisas gerais, e não tanto nas particularidades" (p. 138). Uma das teses mais significativas do livro I dos Discorsi, a nosso juízo, é também uma tomada de posição: "é possível abrir depressa os olhos dos povos, encontrando-se um modo de fazê-los descer aos particulares, vendo que se enganam no geral" (p. 142, o destaque é nosso).
} 
isso porque, enquanto naquela obra a ênfase recai sobre a abstenção de se afirmar ou negar as causas que são oferecidas pela experiência, já nessa última, em função de seu escopo e objeto, joga-se luz sobre outra dimensão do problema, a saber, sobre o esforço de afirmar causas fictícias e, por conseguinte, de negar aquelas oferecidas pela experiência ${ }^{98}$. Entre uma e outra atitudes, há um abismo.

Semelhante argumento reaparecerá anos depois na Ética. Ao falar daqueles que forjam "Deus à parecença do homem, constando de corpo e mente, e submetido às paixões", para além da assertiva irônica de que estes "não entenderem o que eles próprios dizem", deve-se atentar sobretudo para a afirmação de que eles "se esforçam por demonstrar [demonstrare conantur]" o que pretendem ${ }^{99}$. Nessa mesma direção, partindo de um preconceito comum, qual seja, a ignorância inata de todos os homens acerca das causas das coisas e da consequente operação imaginária que antropomorfiza a Natureza na figura de Deus, Espinosa mostra, no Apêndice, como esse preconceito converte-se em superstição pelo cego desejo e insaciável avareza, e o que produziu, a saber, o "máximo esforço" para "inteligir e explicar [intellegere, easque explicare] as causas finais de todas as coisas". Não é por acaso ser apenas nesse momento que se dê o emprego do termo delirium no Apêndice ${ }^{100}$.

No entanto, além do argumento em si, no Tratado Teológico-Político o argumento vem acompanhado de um elemento que julgamos precioso e que não figurará na Ética. Quando, ignorando-se a causa de algo, há o empenho em oferecer uma explicação fictícia para o que percebemos, tem-se uma situação que Espinosa nomeia com um vocábulo muito preciso: extorsio (extorsão). Apesar de figurar, com esse sentido, em apenas três ocasiões na obra - não por acaso, as três no Tratado Teológico-Político, uma obra de combate aberto -, sua importância é capital para o conjunto de questões aqui examinado. Empregado quando Espinosa se refere àqueles que, amparando na Escritura suas próprias ficções, transformam suas opiniões em autoridade teológico-política, trata-se de um vocábulo-chave para o entendimento da gênese da autoridade desprovida de autenticidade e idoneidade.

Uma primeira ocorrência é aquela referente a Maimônides e anteriormente citada ${ }^{101}$. Em outra ocorrência, Espinosa argumenta que "a maior parte [plerumque] dos teólogos está preocupada em saber como extorquir [extorquere] dos Livros Sagrados suas próprias ficções [figmenta] e preceitos

\footnotetext{
98 "estão, portanto, na via errada os que se esforçam por estabelecer a autoridade da Escritura através de demonstrações matemáticas [demonstrationibus conantur]" (Idem, Tratado Teológico-Político, XV, G. 185, p. 230). Cf. também G. 187, p. 232.

${ }^{99}$ ESPINOSA, Ética, I, P 15, p. 69.

${ }^{100}$ Idem, Ética, I, Ap., p. 113.

${ }^{101}$ Idem, Tratado Teológico-Político, I, G. 19, p. 20-1.
} 
[placita], corroborando-as com a autoridade divina"102. Aquela que mais nos interessa é a passagem do capítulo II, em que um caso concreto é apresentado:

Há, todavia, quem, por não querer admitir que se possa verificar alguma mudança nos céus, explique aquela passagem de tal maneira que ela já não parece dizer nada de semelhante; outros, ainda, que aprenderam a filosofar de forma mais correta e sabem que a Terra se move ao passo que o Sol está parado, ou melhor, não se move à volta da Terra, tentam, por todos os meios, extorquir [extorquere] essa verdade da Escritura, por mais que ela diga exatamente o contrário. É realmente de ficar maravilhado ${ }^{103}$.

Essa passagem é especialmente interessante porque nela se demarca com maior clareza a distinção que há pouco fizemos. Que todos vejam o Sol girar em torno da Terra, isso é um dado da imaginação que se dá porque não temos a ideia do Sol e a ideia da Terra em separado, mas simultaneamente. Como tal, nada contém de erro nem de delírio, desde que nos abstenhamos de forjar causas que expliquem o movimento do Sol em torno da Terra. Trata-se de uma percepção natural, que se mantém mesmo quando já sabemos que é a Terra que gira em torno do Sol, pois decorre da natureza do corpo humano (estrutura ótica e cerebral) a visão de que o Sol faz um movimento em torno da Terra ${ }^{104}$. Todavia, quando se procura forjar causas imaginárias para o fenômeno em questão, procurando demonstrá-las e explicá-las como se o Sol de fato fizesse o movimento ao redor da Terra, tem-se o erro advindo da extorsão.

Se examinarmos com atenção essas três passagens, veremos que, nas três, a crítica tem foco: é dirigida não ao comum dos homens, ou, como queira, a todos os homens, mas ao pensamento filosófico e teológico, que procuram converter em explicação e transformar em doutrina aquilo que é pura ficção. Mas isso não é tudo. Deve-se levar em conta que a extorsão é uma

\footnotetext{
${ }^{102}$ Idem, Tratado Teológico-Político, VII, G. 97, p. 114.

${ }^{103}$ Idem, Tratado Teológico-Político, II, G. 35-6, p. 39-40. Nas notas da edição francesa do Tratado Teológico-Político, Lagrée e Moreau informam que a passagem em questão faz alusão a Maimônides e Gersonides, no primeiro caso, e Velthuysen, no segundo (Idem, Traité théologico-politique. Texte établi par Fokke Akkerman; Traduction et notes par Jacqueline Lagrée et Pierre-François Moreau. 2e édition. Paris: Presses Universitaires de France, 2012, p. 712). No entanto, pode-se conjecturar que a passagem faça alusão a Galileu, que procurou conciliar a tese heliocêntrica com as Escrituras. (Cf. GALILEI, G. Ciência e fé. Cartas de Galileu sobre o acordo do sistema copernicano com a Bíblia. Organização e tradução de Carlos Arthur R. Nascimento. 2a edição revista e ampliada. São Paulo: Editora UNESP, 2009.

${ }^{104}$ No Tratado da Emenda do Intelecto, o terceiro modo de perceber é a percepção "em que a essência da coisa é concluída a partir de outra coisa, mas não adequadamente". Uma das situações desse modo é aquela na qual "se conclui a partir de algum universal que sempre é acompanhado de alguma propriedade". Algumas linhas adiante, Espinosa oferecerá um exemplo: "depois que conheci a natureza da visão e simultaneamente que ela possui uma propriedade tal que, a grande distância, vemos uma só e mesma coisa menor do que se a víssemos de perto, concluímos daí ser o Sol maior do que parece, e outros casos semelhantes" (Idem, Tratado da Emenda do Intelecto, §§19, 21, p. 37, 39).
} 
operação que envolve fundamentalmente dois aspectos: $o$ que se extorque (causas imaginárias) e de que se extorque (no caso aqui examinado, das Escrituras). O primeiro tem como base a natureza humana (a potência da imaginação e das causas externas sobre nossa vida afetiva); o segundo, a história (o estabelecimento das Escrituras como fonte e régua da verdade filosófica e da autoridade teológico-política). Esse segundo aspecto é indispensável à compreensão do que aqui se examina na medida em que nele se verifica uma qualificação do problema: se o delírio não necessariamente ampara suas ficções nesse ou naquele objeto com valor social de autoridade historicamente atribuído, a extorsão o faz. Em uma palavra, nos seiscentos extorque quem tem poder e prestígio para tanto. Disso resulta que, nos seiscentos, a autoridade é a um só tempo condição e produto da extorsão ${ }^{105}$.

Para o necessário aprofundamento desse ponto, é indispensável o Prefácio do Tratado Teológico-Político. Tendo nos dois primeiros parágrafos examinado a causa da superstição, Espinosa parte da constatação de que "todos os homens lhe estão naturalmente sujeitos" para, logo em seguida, identificá-los como "vítimas" ou "presas" [capiantur] da superstição e, então, concluir: "não há nada mais eficaz que a superstição para governar as multidões"106. É a partir desse ponto que Espinosa desfere um duríssimo ataque aos filósofos e teólogos:

Inúmeras vezes fiquei espantado por ver homens que se orgulham por professar a religião cristã, ou seja, o amor, a alegria, a paz, a continência e a lealdade para com todos, combaterem-se com tal ferocidade e manifestarem cotidianamente uns para com os outros um ódio tão exacerbado que se torna mais fácil reconhecer a sua fé por vestes do que por aqueles sentimentos. De fato, há muito que as coisas chegaram a um ponto tal que é quase impossível saber se alguém é cristão, turco, judeu ou pagão, a não ser pelo seu vestuário, pelo culto que pratica, por frequentar esta ou aquela igreja, ou finalmente porque perfilha esta ou aquela opinião e costuma jurar pelas palavras deste ou daquele mestre. Quanto ao resto, todos levam a mesma vida [Caeterum vita eadem omnibus est]. Procurando então a causa deste mal, conclui que ele se deve, sem sombra de dúvidas, a

\footnotetext{
${ }^{105}$ Disso há vários exemplos históricos pela negativa, alguns dos quais bem conhecidos. Talvez o mais famoso seja Galileu. Já o caso de Vieira - condenado em 1667 em função de seus escritos messiânicos-milenaristas, parcialmente absolvido no ano seguinte e totalmente apenas em 1675 -, como muitos outros, evidencia o caráter heterogêneo e conflitivo do campo teológico. Já o exemplo de Menocchio, moleiro condenado à morte e executado pela inquisição, é de especial interesse para nós. Examinado pelo historiador Carlo Ginzburg, o exemplo é significativo não só porque permite distinguir, dada a condição social de Menocchio, o comum dos homens dos filósofos e teólogos, mas sobretudo porque evidencia a circulação de ideias e práticas entre os universos popular e letrado na primeira época moderna, o que permite matizar a dominação de que falaremos a seguir. Cf. GINZBURG, C. O queijo e os vermes. O cotidiano e as ideias de um moleiro perseguido pela Inquisição. São Paulo: Companhia das Letras, 2006. Sobre o processo de Vieira, cf. MUHANA, A. (ed.). Os Autos do Processo de Vieira na Inquisição, 1600-1668. Edição, transcrição, glossário e notas de Adma Muhana. São Paulo: EDUSP, 2008.

${ }^{106}$ Idem, Tratado Teológico-Político, Pref., G. 6, p. 7.
} 
consideram-se os cargos da Igreja como títulos de nobreza, os seus ofícios como benefícios, e consistir a religião, para o vulgo, em cumular de honras os pastores. Com efeito, assim que começou na Igreja este abuso [abusus], logo se apoderou dos piores homens [pessimo cuique ingens] um enorme desejo de exercerem os sagrados ofícios, logo o amor de propagar a divina religião se transformou em sórdida avareza e ambição [sordidam avaritiam, et ambitionem]; de tal maneira que o próprio templo degenerou em teatro onde não mais se veneravam doutores da Igreja mas oradores que, em vez de quererem instruir o povo, queriam era fazer-se admirar [admirationem] e censurar publicamente os dissidentes, não ensinando senão coisas novas e insólitas para deixarem o vulgo maravilhado [et ea tantum docendi, quae nova ac insolita, quaeque vulgus maxime admiraretur]. Daí o surgirem grandes contendas, invejas e ódio [contentiones, invidia, et odium], que nem o correr do tempo foi capaz de apagar. Não admira, pois, que da antiga religião não ficasse nada a não ser o culto externo (com que o vulgo mais parece adular a Deus do que adorá-lo) e a fé esteja reduzida a crendices e preconceitos [credulitas et praejudicia]. E que preconceitos estes, que de racionais transformaram os homens em estúpidos [ex rationalibus brutos reddunt], que lhes tolhem por completo [omnino impediunt] o livre exercício da razão e a capacidade de distinguir o verdadeiro do falso, parecendo expressamente inventados para apagar em definitivo a luz do entendimento! A piedade, ó Deus imortal, e a religião consistem em mistérios absurdos [absurdis arcanis] e são os que condenam em absoluto a razão, os que têm aversão e rejeitam o entendimento como coisa corrompida por natureza, são esses, suprema iniquidade [iniquissimum], que passam por possuir a luz divina. Certamente que, se eles tivessem uma centelha que fosse da luz divina, não andariam tão cheios de soberba insana [superbe insanirent] e aprenderiam a honrar a Deus e distinguir-se-iam uns dos outros pelo amor, da mesma forma que se distinguem agora pelo ódio. Nem perseguiriam [persequerentur] com tanta animosidade os que não partilham suas opiniões; pelo contrário, sentiriam piedade deles (se é, de fato, a salvação alheia e não a própria fortuna que os preocupa). Além disso, se realmente tivessem alguma luz divina, ela ver-se-ia pela sua doutrina. Confesso, porém, que apesar da sua insuperável admiração pelos profundíssimos mistérios [mysteria] da escritura, nunca os vi ensinar senão as especulações dos aristotélicos ou dos platônicos [Aristotelicorum vel Platonicorum speculationes], a que adaptaram aquela, ainda assim não parecessem pagãos. Não lhes bastasse já delirarem com os gregos, quiseram também que os profetas delirassem com eles [Non satis his fuit, cum Graecis insanire, sed Prophetas cum iisdem deliravisse voluerunt], o que mostra claramente que nem por sonho reconhecem a divindade da Escritura e que quanto mais se inclinam perante os seus mistérios [mysteria], melhor demonstram que o que sentem por ela não é tanto fé como submissão [assentari]. /.../ Refletindo sobre tudo isto - a saber, que a luz natural é não só desprezada, mas até condenada por muitos como fonte de impiedade; que as invenções humanas [humana commenta] passam por documentos divinos e a crendice [credulitatem] por fé; que as controvérsias dos filósofos desencadeiam na Igreja e no Estado as mais vivas paixões, originando os ódios e discórdias mais violentos, que facilmente arrastam os homens para sublevações [controversias Philosophorum in Ecclesiâ, et in Curiâ summis animorum motibus agitari, ac inde saevissima odia, atque dissidia, quibus homines facile in seditiones vertuntur] e tantas outras coisas que seria 
longo descrever aqui - fiquei seriamente decidido a empreender um novo e inteiramente livre exame da Escritura, recusando-me a afirmar ou admitir como sua doutrina tudo o que dela não ressalte com toda a clareza ${ }^{107}$.

Juntando-se essa longa passagem com o que até aqui observamos, tem-se os contornos de um tipo a um só tempo ético (ódio ${ }^{108}$, avareza ${ }^{109}$, ambição ${ }^{110}$, inveja $^{111}$, desprezo ${ }^{112}$ pela Natureza, admiração e veneração pelos misté$\operatorname{rios}^{113}$, soberba ${ }^{114}$ ), social (culto como elemento de distinção, juramento aos mestres, cargos da igreja como títulos de nobreza, ofícios como benefícios, busca imoderada pelo acúmulo de honras, templo como teatro, oratória para fazer-se admirar) e político (cometimento de abuso, disseminação de discórdias e contendas, defesa da censura, perseguição aos que discordam, submissão aos mistérios para melhor submeter, violência). Três dimensões indissociáveis, cuja unidade encontramos na noção de vida: "todos levam a mesma vida". Com isso, a extorsio tem o potencial de revelar não apenas a norma de pensamento dos teólogos e filósofos, mas igualmente o traço ético, o lugar social e a prática política daqueles a quem é atribuída, formando com isso um verdadeiro tipo epistemológico, ético, social e político ${ }^{115}$.

Assim, se no Apêndice do Livro I da Ética Espinosa busca "convocar os homens ao exame da razão", ele o faz não apenas contra uma inclinação natural de todos os homens a imaginar, mas contra o uso que a autoridade faz dessa inclinação através da organização de preconceitos, convertidos

\footnotetext{
${ }^{107}$ Idem, Tratado Teológico-Político, Pref., G. 8-10, p. 9-11, o destaque é nosso.

108 "O Ódio é a Tristeza conjuntamente à ideia de causa externa" (Idem, Ética, III, Def. dos Afetos 7, p. 345).

109 "A Avareza é o imoderado Desejo e Amor das riquezas" (Idem, Ética, III, Def. dos Afetos 43, p. 363).

110 "A Ambição é o Desejo imoderado de glória" (Idem, Ética, III, Def. dos Afetos 44, p. 363). "A Glória é a Alegria conjuntamente à ideia de uma nossa ação que imaginamos que os outros louvam". (Idem, Ética, III, Def. dos Afetos 30, p. 357).

111 "A Inveja é o Ódio enquanto afeta o homem de tal maneira que se entristece com a felicidade do outro e, inversamente, regozija-se com o mal do outro" (Idem, Ética, III, Def. dos Afetos 23, p. 351).

112 “O Desprezo é a imaginação de uma coisa que toca tão pouco a Mente que esta é levada, pela presença da coisa, a imaginar antes o que não está na própria coisa do que o que está nela" (Idem, Ética, III, Def. dos Afetos 5, p. 343).

113 "A Admiração é a imaginação de uma coisa na qual a Mente permanece fixa, porque esta imaginação singular não tem nenhuma conexão com outras" (Idem, Ética, III, Def. dos Afetos 4, p. 341); “/.../ se o que admiramos é a prudência de um homem, sua indústria ou algo do tipo, dado que por isso contemplamos este homem como nos superando amplamente, então a Admiração é chamada Veneração" (Idem, Ética, III, Def. dos Afetos 52, p. 333).

114 "A Soberba é, por amor de si, estimar-se além da medida" (Idem, Etica, III, Def. dos Afetos 28, p. 353).

${ }^{115}$ É essa perspectiva que informa, segundo depreendemos, o emprego da expressão summus philosophus et theologus no capítulo XIX do tratado: "a isso acresce ainda terem os dogmas da religião aumentado em tão grande número e confundirem-se de tal maneira com a filosofia que o seu supremo intérprete [summus interpres] tinha de ser um grande filósofo e teólogo [summus Philosophus, et Theologus] e atender a uma infinidade de especulações inúteis, o que só era possível a cidadãos particulares com bastante tempo livre" (Idem, Tratado Teológico-Político, XIX, G. 238, p. 298).
} 
em superstições, que "transformaram os homens em estúpidos, que lhes tolhem por completo o livre exercício da razão e a capacidade de distinguir o verdadeiro do falso", e que, "originando os ódios e discórdias mais violentos", acabam facilmente por "[arrastar] os homens para sublevações". Note-se, portanto, que o alvo de Espinosa não é apenas o "esforço por demonstrar" a partir das Escrituras (no caso da tradições judaico-cristãs), mas igualmente - diríamos, sobretudo - os efeitos práticos desse esforço, os quais convergem para a usurpação do poder.

Com isso, a distinção de que antes falamos entre o comum dos homens e os filósofos e teólogos não é apenas de ordem epistemológica - diante das causas que são oferecidas pela experiência, os primeiros abstêm-se de negá-las ao abster-se de forjar causas, os segundos as negam afirmando causas imaginárias -, nem apenas de ordem ética - dados os afetos que predominam em uns e em outros -, mas, sobretudo, de ordem político-social - os primeiros são dominados e subjugados, os segundos dominam e subjugam. Em suma, mais do que uma operação da mente, a extorsio é empregada na obra para designar uma técnica de dominação social e política amparada no medo e no ódio ${ }^{116}$, e que, nos seiscentos, repercutiu em perseguições e violências, cujo gosto amargo Espinosa experimentou ${ }^{117}$. Ao

116 Seja a dominação das mentes, seja a dominação dos corpos (Cf. Idem, Tratado Político, II, §10, p. 17).

117 Embora a perseguição a Espinosa seja um assunto conhecido e abordado já à exaustão, casam com nosso propósito alguns elementos da troca epistolar entre Espinosa e Oldenburg, os quais vale a pena citar. Em carta escrita entre 1661 e 1663, transparecendo hesitar sobre a publicação ou não do Tratado da Emenda do Intelecto, Espinosa confidencia a Oldenburg: "temo que os teólogos de nosso tempo se ofendam e invistam contra mim, que tenho completo horror a rixas, o ódio com que estão acostumados" (Idem, "Correspondência entre Espinosa e Oldenburg", Ep. 6, p. 131). Em carta datada de 04 de agosto de 1663, Oldenburg ecoa os temores que Espinosa lhe confidenciara: informando-lhe ter certeza de que na Inglaterra os filósofos não hão de faltar com seu dever - referindo-se ao método experimental -, o secretário da Royal Society complementa: "e não menos tenho me persuadido de que também hás de cumpri-lo com ardor em teu país, o que quer que o vulgo, seja dos filósofos, seja dos teólogos [sive Philosophorum, sive Theologorum vulgus], rosne ou incrimine" (Idem, "Correspondência entre Espinosa e Oldenburg", Ep. 16, p. 157). Dois anos depois, no entanto, fazendo apologia da "República Filosófica", Oldenburg tentará convencer Espinosa a publicar seus escritos: "Por que hesitas, meu amigo, o que temes? Tenta, começa, perfaz encargo de tanta importância, e verás patrocinar-te todo o coro dos que verdadeiramente filosofam [totum verè Philosophantium Chorum]". Em sua resposta, Espinosa silenciará sobre o assunto: "sobre as demais coisas, em outra ocasião" (Idem, "Correspondência entre Espinosa e Oldenburg", Ep. 31 e 32, p. 172, 180). Finalmente, em 1675, quando o Tratado Teológico-Político já circulava havia dez anos e a Ética acabara de ser finalizada, Espinosa queixa-se do rumor, ao qual muitos davam crédito, de que um novo livro seu sustentaria a não existência de Deus. Diz ele a seu correspondente: "alguns teólogos (talvez, os autores desse rumor) agarrarem a ocasião para queixar-se de mim perante o Príncipe e os magistrados", e complementa: "como eu soubera dessas coisas por alguns homens fidedignos, que, simultaneamente, afirmavam que os teólogos me insidiavam por toda a parte, decidi prorrogar a edição que preparava, até que eu visse em que acabaria o assunto, e então sinalizar-te que plano que eu seguiria. Mas o assunto parece a cada dia inclinar-se ao pior, e estou incerto sobre o que farei". (Idem, "Correspondência entre Espinosa e Oldenburg", Ep. 68, p. 190). 
fim e ao cabo, o que está em jogo com o emprego de semânticas distintas para o comum dos homens e para os filósofos e teólogos é a depreensão de uma relação de poder.

\section{O paradoxo da Filosofía e da Teologia: discrepância como impotência, discrepância como potência}

Temos agora condições de voltar ao início e examinar o sentido do parágrafo que abre o Tratado Político. Inicialmente, cumpre explorar a aparente contradição entre o dito parágrafo e o que mostramos há pouco com base no Tratado Teológico-Político.

Segundo nosso autor, como resultado de conceberem os homens não como são, mas como gostariam que fossem, os filósofos "nunca tenham concebido política que possa ser posta à prova pelo uso [ad usum revocari], mas política que é tida por quimera ou que só poderia instituir-se [institui] na utopia ou naquele século de ouro dos poetas, onde sem dúvida não seria minimamente necessária". Não podendo ser postas à prova pelo uso nem instituir-se, as teorias de filósofos e teólogos seriam como que inofensivas, sem eficácia, incapazes de ter desdobramentos ou efeitos práticos - tal como asseveram os comentadores. Ora, não só essa hipótese é contrafactual do ponto de vista histórico - pois, conforme a pesquisa histórica tem mostrado, filósofos e teólogos não apenas tomaram parte nos assuntos comuns como exerceram influência sobre a política em vários de seus domínios não só na primeira época moderna, mas desde a antiguidade ${ }^{118}$ -, como o exame aqui realizado revela que Espinosa não considerava a filosofia e a teologia como inofensivas, antes reconhecia nelas o potencial de produzir sujeição epistemológica, ética, política e social. Como resolver a aparente contradição?

Para que se enfrente essa questão, o primeiro passo consiste em situar o conceito de discrepância, empregado quando Espinosa argumenta ser "na política que a teoria é mais discrepante [discrepare] da prática". Para tanto, é essencial tomarmos um Escólio da Ética, examinando com muito cuidado seus termos:

Eu disse que Paulo odeia Pedro porque imagina [imaginatur] que este possui o que [quod] o próprio Paulo também ama; donde, à primeira vista, parece

\footnotetext{
${ }^{118}$ No capítulo XIX do Tratado Teológico-Político, Espinosa faz alusão à gênese histórica da influência dos filósofos em imperii cristãos: "quando, porém, passados muitos anos, a religião começou a introduzir-se no imperium, os eclesiásticos tiveram de a ensinar, tal como a haviam definido, aos próprios imperadores, o que lhes valeu serem reconhecidos como seus doutores e intérpretes e bem assim como pastores da Igreja e vigários de Deus" (Idem, Tratado Teológico-Político, XIX, G. 238, p. 298).
} 
seguir que estes dois sejam danosos um ao outro por amarem o mesmo e, consequentemente, por convirem em natureza /.../. Todavia, se quisermos examinar a coisa com uma justa balança, veremos que tudo convém inteiramente [omnia convenire omnino]. Pois os dois não são molestos um ao outro enquanto convêm em natureza, isto é, enquanto ambos amam o mesmo, mas enquanto discrepam [discrepant] um do outro. De fato, enquanto amam o mesmo, por isso o amor de ambos é fomentado (pela prop. 31 da parte III), isto é (pela 6 $6^{\mathbf{a}}$ def. dos Afetos), por isso a Alegria de ambos é fomentada. Em consequência, estão longe de ser molestos um ao outro enquanto amam o mesmo e convêm em natureza. Mas a causa disto, como eu disse, não é outra senão que se supõe que discrepam [discrepare supponuntur] em natureza. Pois supomos [supponimus] que Pedro tem a ideia da coisa [rei] amada possuída agora, e Paulo, ao contrário, tem a ideia da coisa [rei] amada perdida. Donde ocorre que este seja afetado de Tristeza e aquele, ao contrário, de Alegria; e nesta medida são contrários um ao outro. Desta maneira podemos mostrar facilmente que as outras causas de ódio dependem somente de que os homens discrepem [discrepant] em natureza, e não daquilo em que convêm ${ }^{119}$.

Desse Escólio, é necessário reter três coisas: em primeiro lugar, a afirmação de que "tudo convém inteiramente"; em segundo lugar, que na discrepância predominam a imaginação (e a aparência) e a externalidade - daí termos destacado os vocábulos quod e res ${ }^{120}$; em terceiro lugar, e em decorrência desse segundo ponto, que a discrepância consiste, em última instância, em uma suposição. A esses três apontamentos, some-se um quarto, extraído da Epístola 32: a discrepância envolve uma operação de separação ${ }^{121}$. Nessa medida, porque separa a parte do todo e a transforma imaginariamente em todo, a discrepância conduz à abstração ${ }^{122}$.

Como se pode notar, a necessária atenção ao conceito de discrepância abre um horizonte fértil para a interpretação do parágrafo de abertura do Tratado Política. Pois, se a discrepância entre teoria e prática tal como

${ }^{119}$ Idem, Ética, IV, P 34, Esc., p. 425, o destaque é nosso.

${ }^{120}$ Sobre isso, considere-se o lugar da aparência no Apêndice do Livro I e o lugar da causa externa na Proposição 33 do Livro IV: Idem, Ética, I, Ap., p. 119-21; IV, P 33, Dem., p. 423. ${ }^{121}$ Lemos na Epístola 32: "considero as coisas como partes de um certo todo enquanto a natureza delas acomoda-se uma à outra, de maneira que consintam entre si [invicem se accommodat] o quanto possível; mas enquanto discrepam entre si [inter se discrepant], cada uma forma em nossa mente uma ideia separada das outras [ideam ab aliis distinctam in nostra Mente forma], e por isso é considerada [consideratur] como um todo, não como uma parte" (Idem, A correspondência entre Espinosa e Henry Oldenburg, p. 32, p. 176). Contrariamente a Ferreira, que traduziu discrepant por "distinta", optamos por "separada" para demarcar o sentido do que é dito, evitando a confusão com a ideia clara e distinta.

122 Segundo Espinosa, "quando algo é concebido abstratamente, como são todos os universais, esses sempre são compreendidos mais amplamente [latius] no intelecto do que seus particulares [eorum particularia] podem existir deveras na Natureza", e complementa: "[é-nos] antes de tudo necessário que sempre deduzamos todas as nossas ideias das coisas físicas, ou seja, dos seres reais, indo, quanto se pode fazer segundo a série das causas, de um ser real para outro ser real, de modo a não passarmos a ideias abstratas e universais, quer não deduzindo delas nada de real, quer não as concluindo de coisas reais" (Idem, Tratado da Emenda do Intelecto, $\S \S 76,99$, p. 75,89 , o destaque é nosso). 
anunciada é uma aparência na qual a prática figura como algo exterior em relação à teoria porque foi dela separada - não por acaso, é dito que "se crê" [creditur] que a teoria é discrepante da prática -, e se, ao forjá-la como um todo, se a toma como universal ("a teoria"), cumpre remetê-la de volta à prática ${ }^{123}$ - isto é, à pratica, entendida como experiência comum, e à sua prática, entendida como experiência particular ${ }^{124}$. Em outras palavras, diante das teorias aparentemente vazias de filósofos e teólogos, é o caso de indagar: qual prática as engendra e conserva? Inversamente, qual prática elas alimentam? ${ }^{125}$ Como procuramos mostrar nas linhas acima, esta é oferecida ao longo da obra, em especial, e não por acaso, no Tratado Teológico-Político, no qual Espinosa pratica uma historiografia.

A colocação à prova de nossa hipótese exige que entendamos por que Espinosa optou por uma abstração no parágrafo que abre o Tratado Político. A resposta a essa pergunta requer que se considere o escopo desse escrito e seu lugar diferencial no interior da obra de Espinosa, bem como a qualificação dos dois primeiros parágrafos do Tratado Político ${ }^{126}$. É o que faremos agora.

Para tanto, será útil, como ponto de partida, distinguirmos os verbos que Espinosa emprega ao fazer menção aos filósofos, no primeiro parágrafo, e aqueles por ele empregados quando fala dos políticos, no segundo. Sumariamente, enquanto os filósofos "concebem" (três vezes), "riem", "choram", "censuram", "detestam", "creem", "aprendem", "louvam", "fustigam", "escrevem" e, finalmente, "são menos idôneos", já os políticos,

\footnotetext{
${ }^{123}$ Quando há pouco dissemos, ao tratar da teoria do conhecimento em Espinosa, que não assentir significa abster-se de afirmar ou negar as causas que são oferecidas pela experiência e que conduziriam a concluir que a ideia é fictícia, o pressuposto é que há uma experiência que lhe é imanente. Assim, ao contrário de filósofos e teólogos, a nós cumpre seguir a recomendação de Espinosa se quisermos não realizar ficções acerca das ficções de filósofos e teólogos e de suas repercussões práticas: "quando [a existência] é concebida particularmente, mais claramente, então, é entendida, e mais dificilmente é forjada em algo a não ser na própria coisa, quando não atentamos à ordem da Natureza" (Idem, Tratado da Emenda do Intelecto, $\S \S 58$, p. 61). Em suma, não cabe abordar "a teoria" como se esta fosse um universal; antes, é preciso confrontá-la no que ela tem de particular.

${ }^{124} \mathrm{Na}$ obra de Espinosa, o termo praxis é associado à experiência, à natureza humana e à condição comum dos homens. Sendo histórica e envolvendo uma pluralidade [multitudo] de indivíduos, trata-se do campo comum de experiências marcado pela pluralidade. Cf., p. ex., Idem, Tratado Político, I, §3, p. 7; XI, §2, p. 138.

${ }^{125}$ Corrobora nossa hipótese o fato de, poucas linhas depois da assim dita discrepância entre teoria e prática ter sido evocada, ao anunciar o objetivo envolvido na escrita do Tratado Político, Espinosa não dizer que deduzirá da condição da natureza humana o que convém com a prática, mas sim algo que "melhor" [optme] convém com a prática (Idem, Tratado Político, I, §4, p. 7-8). Pelo que observamos no tratado, o melhor passa por arranjos institucionais que aproximem o imperium da democracia, o que garantirá sua estabilidade. Do que podemos inferir que a instabilidade é o preço de certas maneiras de convir com a prática e que fogem dessa que é a melhor, o que é sublinhado em várias passagens do tratado.

${ }^{126}$ Como se sabe, o primeiro parágrafo do Tratado Político é dedicado aos filósofos e o segundo, aos políticos. Contrapondo-se a ambos, ou à maneira como cada um desses tipos concebe a política, no terceiro e quarto parágrafos Espinosa anuncia a abordagem que ele realizará, ou sua própria concepção.
} 
"não cuidam", “armam ciladas", "são habilidosos", "procuram precaver-se", "usam", "escrevem" e "ensinam". O que essa distinção revela?

Se Espinosa abre o segundo parágrafo valendo-se de uma conjunção adversativa - "pelo contrário" [contra] -, marcando a contrariedade em relação ao que fora dito no parágrafo anterior, é necessário observar que a contrariedade não se resume, como à primeira vista pode parecer, à maneira como cada um desses tipos concebe os homens. Na verdade, há uma segunda contrariedade embutida na passagem, não tão explícita quanto a primeira, mas tão ou mais importante que ela: enquanto os filósofos são criticadas por Espinosa sobretudo pelo que dizem e escrevem - não é menor a restrição feita por Espinosa: diante da natureza humana, nosso autor não diz que os filósofos a fustigam, mas que a fustigam "com sentenças" [dictis lacessere] -, já os políticos são criticados sobretudo pelo que fazem ${ }^{127}$.

Se a abertura do Tratado Político tem como objeto não a maneira como os filósofos vivem ou sua prática, mas seus escritos, é forçoso notar que a restrição está de acordo com o propósito e o escopo dessa obra: procurando não descrever nem explicar, mas demonstrar ou deduzirr ${ }^{128}$, o Tratado Político pretende deslocar o terreno no qual se escreve sobre política. Essa é a razão pela qual, ao final do segundo parágrafo, Espinosa conclui ser "inquestionável que os políticos escrevem [scripsisse] sobre as coisas políticas de maneira muito mais feliz do que os filósofos" ${ }^{129}$ : ou seja, a despeito de tudo o que os políticos fazem e que fora observado por Espinosa, quando a comparação entre filósofos e políticos é finalmente realizada, é especificamente na escrita que ela reside. Da mesma maneira, julgamos estar aqui a razão de Espinosa poder advertir, ainda no primeiro capítulo, sem prejuízo algum para a contribuição original do tratado, não ter tido a pretensão de demonstrar nem deduzir "nada que seja novo ou jamais ouvido [nihil novum vel inauditum est]" naquela obra: pois, se os resultados a que chega o Tratado Político são familiares, posto que dados pela experiência, o caminho inaugurado por Espinosa é novo: uma escrita baseada na ciência dos afetos. Em outras palavras, a despeito do que será dito, o Tratado Político inaugura outra maneira de escrever sobre isso que será dito. Mas há que se fazer uma ressalva: de certa forma, também o resultado do empreendimento é novo, pois como o conhecimento do efeito envolve o conhecimento da causa ${ }^{130}$, essa escrita, procurando inteligir as ações humanas ${ }^{131}$, oferece o conhecimento do que antes era apenas percebido. Podemos então dizer que o Tratado Político está para os discursos agudos e prudentes sobre a política assim como a Filosofia está

\footnotetext{
${ }^{127}$ No já mencionado Prefácio do Livro III da Ética, Espinosa igualmente circunscreve a crítica aos filósofos pelo que "escreveram" [scripserunt] sobre os afetos e a maneira de viver dos homens (Idem, Ética, III, Pref., p. 233).

${ }^{128}$ Idem, Tratado Politico, I, §4, p. 7-8.

${ }^{129}$ Idem, Tratado Político, I, §2, p. 6-7.

${ }^{130}$ Idem, Ética, I, Ax. 4, p. 47.

${ }^{131}$ Idem, Tratado Político, I, §4, p. 7-8.
} 
para a Escritura: uma pela certeza matemática dada pela ciência dos afetos (com o apoio da experiência), outra pela certeza moral dada apenas pela experiência, ambas são maneiras diferentes de chegar ao mesmo ponto. No caso em questão, o ponto é a segurança.

A restrição do escopo do Tratado Político ao universo do discurso ou da escrita sobre a política explica em parte a discrepância a que o parágrafo de abertura faz alusão. Limitando-se o escopo aos escritos de filósofos e teólogos, abstraídos da prática que os engendra e conserva, estes escritos parecem discrepar da prática. Mas, como acabamos de dizer, o escopo do tratado apenas em parte explica a opção de Espinosa.

Com vistas a dar conta da questão, recorreremos ao exame de uma passagem presente no segundo parágrafo do Tratado Político, a qual se oferece para nós como uma senha para o enfrentamento da questão:

Daí que, ao procurarem precaver-se da malícia humana por meio daquelas artes que uma experiência de longa prática ensina e que os homens, conduzidos mais pelo medo que pela razão, costumam usar, [os políticos] pareçam [videntur] adversários [adversari] da religião, principalmente dos teólogos, os quais creem que as potestades soberanas devem tratar dos assuntos públicos segundo as mesmas regras da piedade que tem um homem particular ${ }^{132}$.

Atente-se: Espinosa não afirma que os políticos "são" adversários dos teólogos - como era de se esperar caso se tome como verdadeiro o que, na passagem, é dito de uns e de outros -, mas que "parecem" ser. Não se trata de mera minúcia desprovida de importância. Pois, a confiar na precisão dos termos empregados por Espinosa, ou bem os políticos fingem procurar precaver-se da malícia humana por meio de certas artes quando, na verdade, creem na piedade em se tratando de assuntos públicos, ou bem os teólogos fingem crer nas regras de piedade em se tratando de assuntos públicos quando, na verdade, agem da mesma forma que os políticos. Como a experiência largamente ensina que a primeira hipótese é falsa, a segunda só pode ser verdadeira - conforme Espinosa mostra no Tratado Teológico-Político. Por trás da afirmação segundo a qual os políticos apenas "parecem" ser adversários dos teólogos, evidencia-se, na verdade, que são os teólogos que apenas "parecem" ser adversários dos políticos: da perspectiva do que escrevem, parecem; já da perspectiva de como vivem e do que fazem, são estes que se assemelham àqueles.

O fato de os teólogos apenas parecerem adversários dos políticos não é lateral. Bem ao contrário, em sintonia com todo o exame até aqui realizado, o argumento mostra-se como uma chave para a interpretação da abertura do Tratado Político, afinal, é a distinção entre estes de quem agora se infere serem semelhantes que a abertura pretensamente quis realizar. Ao lado do conjunto de apontamentos até aqui realizado, ela indica que os dois parágrafos que abrem o Tratado Político devem ser vislumbrados como

${ }^{132}$ Idem, Tratado Político, I, §2, p. 6-7. 
uma estrutura argumentativa cujo escopo não é descritivo, ou seja, não é destes ou daqueles filósofos e políticos em contextos históricos determinados que fala - razão pela qual Espinosa pôde dizer que os teólogos apenas parecem ser adversários dos políticos.

Nossa hipótese é de que os filósofos e os políticos a que se faz alusão nessas passagens são tipos éticos, políticos e sociais em contraste, imagens forjadas que uns fazem dos outros. Ao lado dos argumentos já evocados, a fundamentação de nossa hipótese volta-se também para o método: quando, no quarto parágrafo, falando da política, Espinosa informa que irá "investigar [inquirerem] aquilo que respeita a esta ciência com a mesma liberdade de ânimo [animi libertate] que é costume nas coisas matemáticas"133, essa investigação começou já pelos parágrafos que abrem o tratado, de modo que os filósofos e os políticos ali evocados são constituídos more geometrico.

Quanto à maior parte dos filósofos e teólogos históricos, de carne e osso, o exame da obra sugere que estes situam-se em ambos os tipos: se atentarmos para o que escrevem, situam-se no tipo "filósofo", mas, se atentarmos para a vida que levam e para o que fazem - o que só a consideração do Tratado Teológico-Político permite vislumbrar -, situam-se no tipo "político". Já o oposto não é verdadeiro, e essa não é uma diferença marginal, seja do ponto de vista prático, seja do ponto de vista analítico - e com isso atingimos o cerne de nossa argumentação: ainda que os políticos "escrevam sobre as coisas políticas de maneira muito mais feliz do que os filósofos", o fato de os políticos em geral não se situarem no tipo "filósofo" subtrai de seus escritos autoridade - ao menos nos seiscentos, em que a eficácia política dos escritos dos filósofos e teólogos como técnica de sujeição e de dominação é inegável ${ }^{134}$. Em outras palavras, do ponto de vista da crítica, importa menos o fato de a teoria dos filósofos e teólogos não ser a que melhor convém com a prática; importa antes de tudo reconhecer que, de alguma maneira, convém, e, em seguida, ver qual é o uso que dela se faz - um uso em tudo diverso à imagem que os políticos dela têm, imbuídos que estão não em enxergar a praxis imanente à teoria de seus adversários, mas em afirmar a própria teoria ${ }^{135}$. Aqui, mais uma vez, o Tratado Teológico-Político é indispensável.

Disso não resulta que todo o parágrafo de abertura do Tratado Político contenha tão somente a dedução do filósofo. Em consonância com o res-

\footnotetext{
${ }^{133}$ Idem, Tratado Político, I, §4, p. 7-8.

134 Justamente porque "decisões políticas não podem ser avaliadas pela sua verdade ou falsidade, mas por sua eficácia, a qual é a 'verdade' da coisa política" (CAMPOS, Spinoza's Revolutions in Natural Law, p. 168), e haja vista que, historicamente, decisões foram informadas por teorias de filósofos e teólogos, é que consideramos necessário ultrapassar o senso comum na consideração do argumento da idoneidade dos filósofos para o governo da República.

135 Realizado por Espinosa no parágrafo aqui discutido, o contraste entre usus e praxis tem relevância por isso. Diversamente de praxis, empregada para designar um campo compartilhado de experiências, o vocábulo usus figura de maneira muito mais abundante na obra e designa o emprego de algo por alguém em dado contexto. Se o uso observa a regras, tais regras não são dadas externamente e não moldam o uso de maneira normativa, antes são
} 
tante dessa obra, também aqui dedução e experiência complementam-se na escrita, de modo que o parágrafo pode, a nosso juízo, ser dividido em duas partes: a dedução do tipo filósofo (do início até "fossem"); a imagem forjada pelos políticos, na experiência, do tipo filósofo (de "De onde resulta

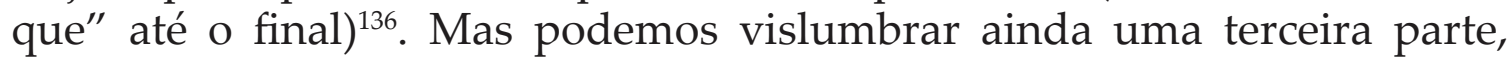
sobreposta à segunda, no trecho "não há ninguém menos idôneo [nulli minus idonei] para o governo de uma república do que os teóricos ou os filósofos". Aqui concentra-se a resposta à questão antes levantada, sobre a razão de Espinosa ter optado por uma abstração.

À luz do que observamos ao longo do presente artigo a respeito da prática de filósofos e teólogos, podemos dizer que, como em outras partes da obra, também no parágrafo de abertura do Tratado Político verifica-se uma estratégia de argumentação na qual uma tese é afirmada passando pelo seu avesso, ou seja, o conceito é extraído da imagem no momento mesmo em que Espinosa dá voz ao vulgo ${ }^{137}$ : assim, se é verdade que nos seiscentos não há ninguém menos idôneo para o governo de uma República do que filósofos (e teólogos), isso ocorre não porque suas teorias sejam politicamente inofensivas, como vulgarmente se pensa, mas, bem ao contrário, justamente porque tais teorias, vocacionadas que são para a realização de seu ideal normativo, são perigosas. Dito de outro modo, em se tratando da concepção de política dos filósofos e teólogos seiscentistas, no interior mesmo da imagem vulgar da discrepância entre teoria e prática como impotência política, está contido (e, portanto, revela-se) o conceito da conveniência entre teoria e prática como potência política ${ }^{138}$.

Com isso, emerge sob a pena de Espinosa o paradoxo da filosofia e da teologia na primeira época moderna: o discurso da transcendência,

imanentes ao uso. Com isso, a depreensão das verdadeiras regras depende sempre de um exame atento do uso. Podemos dizer que o uso está para a regra assim como a prática está para a teoria. Para um estudo sobre a relação entre uso e regra na linguagem em Espinosa, cf. SANTIAGO, H. Geometria do instituído. Estudo sobre a gramática hebraica espinosana. Fortaleza: EDUECE, 2014.

${ }^{136}$ Daí o emprego das expressões "as mais das vezes [plerumque]", "é tida por [haberetur]", "se crê [creditur]", considera-se [aestimantur]".

${ }^{137}$ Cf. DAVID, A. "O vulgo e a interpretação da obra de Espinosa". Neste artigo, apoiamo-nos no estudo de Chaui sobre o "contradiscurso" de Espinosa.

${ }^{138}$ A discrepância é uma impotência da mente (a rigor, uma impotência da mente para distinguir de maneira clara e distinta, mas uma potência para forjar). Mas, uma vez que toda teoria de alguma maneira convém com $a$ prática e na medida em que convém com sua prática, toda teoria pode ser dotada de potência política. É o caso de teorias de filósofos e teólogos na época de Espinosa. Com isso, colocamo-nos em contraposição às leituras realizadas pelos comentadores e resumidas no início. As lacunas que nelas observamos são mais evidentes, a nosso juízo, em Matheron. Em primeiro lugar, falando da absoluta inaptidão dos filósofos, Matheron sustenta que, aos olhos de Tomás de Aquino, ainda que a praxis politica esteja muito afastada de fato da teoria, de direito não estaria. Ora, justamente porque, em Espinosa, direito é potência - o que elimina a clivagem "de direito" $x$ "de fato" -, a crítica de Matheron ficou no meio do caminho (p. 93). Ademais, embora chegue a reconhecer a "utilização política da religião", Matheron não tira daí todas as consequências, antes restringe-as ao campo ideológico, reportando-se a uma "teoria das ideologias" supostamente compartilhada 
justamente por afirmar como os homens deveriam ser - o que o torna aparentemente descolado da realidade -, converteu-se na mais poderosa técnica de dominação e de sujeição dos homens tal como estes efetivamente são $^{139}$. A alusão à discrepância entre teoria e prática presente na abertura do Tratado Político ultrapassa a mera constatação da impotência da mente para, de seu interior mesmo, explicar de que maneira filósofos e teólogos, mesmo sendo impotentes à luz da Ética espinosana, e talvez porque fossem impotentes (haja vista a prática predominante no contexto), jogaram um papel político central no limiar da modernidade, uma verdadeira potência política da servidão. O segredo do paradoxo, insistimos, reside na prática histórica que o engendrou, alimentou e conservou ${ }^{140}$.

Nesse sentido, à luz das pesquisas históricas recentes, salta aos olhos a potência da crítica realizada por Espinosa, como crítica histórica, à idoneidade de filósofos e teólogos. Quanto a isso, e reportando-nos finalmente às interpretações a que fizemos menção no início, podemos dizer, em uma palavra, que o apreço de Espinosa pela história passou despercebido pelos comentadores ${ }^{141}$. Todavia, com Espinosa e com a história aprendemos que,

por Hobbes e Espinosa (p. 103-4). Enfim, porque sumariza a contribuição de Espinosa como "não mais determinação de normas que a praxis deveria seguir, mas ciência puramente especulativa que terá a praxis ela mesma por objeto" (p. 110), e a despeito da grande erudição e consistência de seu trabalho, Matheron acabou por não ver que, para Espinosa, tão ou mais importante que a crítica da normatividade é a crítica da praxis histórica daqueles que agem sob o ideal da normatividade.

${ }^{139}$ Em outro artigo, publicado na mesma coletânea, Matheron volta ao parágrafo primeiro do Tratado Político: “O que se passaria no Estado se todos fossem racionais? Spinoza diz aqui - referindo-se ao parágrafo quinto -, como já havia dito no capítulo $\mathrm{V}$ do Tratado Teológico-Político e como voltará a dizer no parágrafo primeiro do capítulo I do Tratado Político: nada ocorreria, pois os homens entrariam em acordo sem qualquer obrigação e o Estado simplesmente não existiria" (p. 199). Esse argumento é ao nosso ver exemplar porque localiza a lacuna interpretativa: esta reside na perspectiva adotada. Pois aqueles que concebem os homens não como são, mas como deveriam ser, não se ocupam somente sobre o que ocorreria se os homens fossem racionais (ou pios), mas, sobretudo, do que deve ser feito sabendo-se que os homens não são o que se supõe que deveriam ser. Essa, e não aquela perspectiva tem relevância histórica.

${ }_{140} \mathrm{O}$ pressuposto de que partimos é que o discurso não se resume a representações de uma realidade a ser conhecida, nem é apenas expressão de uma prática histórica da qual é constitutivo; também o discurso é aqui tomado como prática dotada de eficácia política. Podemos olhar para o Tratado Político sob essas duas perspectivas: por um lado, como um discurso que fala de práticas históricas - nesse sentido, seu projeto é a dedução de arranjos institucionais que favoreçam práticas de equidade e desfavoreçam seu contrário, e que podem ter lugar total ou parcialmente em contextos históricos determinados; por outro lado, como um discurso que é uma prática histórica e, como tal, tem a pretensão de eficácia política - aqui, pensamos que seria o caso de investigar a história do esquecimento dessa obra desde seu aparecimento até nossos dias, em contraste com aquelas obras de fundamentação da política que no passado mereceram e/ou ainda merecem a atenção de muitos.

${ }^{141}$ Parece-nos especialmente emblemático o fato de, ao mesmo tempo em que sublinhavam a impotência envolvida na teoria de filósofos e teólogos, alguns comentadores terem identificado o alvo principal de Espinosa na Segunda Escolástica. Isso porque os teólogos da Segunda Escolástica jogaram um papel decisivo na justificação e, por conseguinte, na montagem dos impérios ibéricos na América. Ao lado dos comentadores já examinados, considere-se os argumentos de Delbos e Del Lucchese: o primeiro argumenta que "o erro da maioria dos 
seja atuando em prol da liberdade, seja atuando em prol da servidão, Filosofia e Teologia são armas perigosas ${ }^{142}$.

\section{Referências bibliográficas}

AURÉLIO, D. P. Imaginação e poder. Estudo sobre a filosofia política de Espinosa. Lisboa: Edições Colibri, 2000.

B AliB AR, E. Spinoza et la politique. Réimpression de la 3' édition. Paris: Presses Universitaires de France, 2005.

CAMPOS, A. S. "Spinoza and the paradox of political freedom". Conatus. Vol. 8, no 16, dez. 2014, p. 11-24.

Spinoza's Revolutions in Natural Law. New York: Palgrave Macmillan, 2012, p. 168.

CHAUI, M. A nervura do real II. Imanência e liberdade em Espinosa (Vol. 2 - Liberdade). São Paulo: Companhia das Letras, 2016.

Política em Espinosa. São Paulo: Companhia das Letras, 2003.

CRISTOFOLINI, P. “Spinoza e l'acutissimo fiorentino". In: . Spinoza hedonista. Pisa: EDS, 2002, p. 25-40.

teólogos e filósofos, segundo Spinoza, é crer que a lei que comanda pode, unicamente porque é a lei, nos conduzir à salvação" (DELBOS, V. "O problema moral na filosofia de Spinoza". Tradução de Martha de Aratanha. Conatus. Vol. 7, nº 13, jul. 2013); já o segundo argumenta que, em Espinosa, a teoria política "não pode ser deduzida de regras abstratas e gerais, mas deve se reportar à essência de coisas particulares", razão pela qual os filósofos seriam, para nosso autor, os menos idôneos ao governo da República (DEL LUCCHESE, F. Tumultes et indignation. Conflit, droit et multitude chez Machiavel et Spinoza. Traduit de l'italien par Pierre Pasquini. Paris: Éditions Amsterdam, 2010, p. 245). Ora, o contexto da colonização da América forçou o debate, no interior da Segunda Escolástica, a respeito da observância das contingências históricas nas elaborações teóricas de justificação da ocupação, da exploração e, em particular, do cativeiro negro e indígena. Seguramente Espinosa não era indiferente a nada disso. Sobre este ponto, cf. ZERON, C. A. R. M. Linha de fé. A Companhia de Jesus e a escravidão no processo de formação da sociedade colonial (Brasil, séculos XVI e XVII). São Paulo: Edusp, 2011; MARCOCCI, G. A consciência de um império. Portugal e o seu mundo (sécs. XVI-XVII). Coimbra: Imprensa da Universidade de Coimbra, 2012.

${ }^{142}$ Com isso, subscrevemos apenas em parte a conclusão de Santiago à pergunta que dá título a um artigo seu: "já que os valores são necessários, tratemos nós de forjá-los em vista da alegria e do benefício à vida. Poder fazê-lo talvez seja o mais difícil; mas precisamos fazê-lo. Se não o fizermos, se nos restringirmos ao mais fácil, o preconceito, a tristeza, a superstição e o seu lugar-tenente - o teólogo - o farão por nós". Apegado a uma imagem do teólogo, julgamos que Santiago esqueceu-se não só de que o filósofo também tem ocupado esse lugar historicamente, como também de que, tanto quanto o filósofo, também o teólogo pode tomar parte na produção da liberdade (SANTIAGO, S. “O filósofo espinosano precisa criar valores?". Trans/Form/Ação. São Paulo, 30(1), 2007, p. 148). Em vista de tudo o que expusemos no presente artigo, a questão que nos interessaria responder não é se, mas de que maneira o filósofo e o teólogo, espinosano ou não, podem criar e efetivamente criam valores que favoreçam a democracia e a liberdade em contextos históricos desfavoráveis para tanto. 
CURLEY, E. “Kissinger, Spinoza, and Genghis Khan”. In: GARRETT, D. (ed.). The Cambridge Companion to Spinoza. Cambridge University Press, 2006, p. 315-42.

D AVID, A. “O vulgo e a interpretação da obra de Espinosa". Cadernos Espinosanos. São Paulo, nº 39, jul.-dez. 2018, p. 141-62.

FRAENKEL, C. "Spinoza's philosophy of religion”. In: Della Rocca, M. (ed.). The Oxford Handbook of Spinoza. New York: Oxford University Press, 2018, p. 377-407.

DEBRABANDER, F. Spinoza and the stoics. Power, Politics and the Passions. London: Continuum, 2007.

DEL LUCCHESE, F. Tumultes et indignation. Conflit, droit et multitude chez Machiavel et Spinoza. Traduit de l'italien par Pierre Pasquini. Paris: Éditions Amsterdam, 2010.

DELBOS, V. “O problema moral na filosofia de Spinoza”. Tradução de Martha de Aratanha. Conatus. Vol. 7, nº 13, jul. 2013, p. 69-76.

ESPINOSA, B. “Carta 44". Tradução, introdução e notas Antônio David. Cadernos de Ética e Filosofia Política, nº 20, p. 178-81.

. (SPINOZA, B.). Correspondencia completa. Traducción, introducción, notas e índices Juan Domingo Sánchez Estop. Madrid : Hiperión, 1988.

. "Correspondência entre Espinosa e Oldenburg". In: FERREIRA, S. T. A correspondência entre Espinosa e Henry Oldenburg. Dissertação (Mestrado em Filosofia). Faculdade de Filosofia, Letras e Ciências Humanas. Universidade de São Paulo, 2019, p. 103-219.

. "Epístolas: Espinosa e Boxel". Apresentação, preparação do texto latino, tradução e notas Samuel Thimounier. Revisão técnica Homero Santiago. Cadernos Espinosanos, no 35, jul-dez 2016, pp. 523-71.

Ética. Tradução Grupo de Estudos Espinosanos; coordenação Marilena Chaui. São Paulo: Editora da Universidade de São Paulo, 2015.

- Princípios de filosofia cartesiana e Pensamentos metafísicos. Tradução Homero Santiago, Luis César Guimarães Oliva. Belo Horizonte: Autêntica, 2015.

(SPINOZA, B.). Spinoza Opera. Im Auftrag der Heidelberger Akademie der Wissenschaften hrs. von Carl Gebhardt. Heidelberg: C. Winter, 1972.

Tratado da emenda do intelecto. Tradução Cristiano Novaes de Rezende. Campinas: Editora da Unicamp, 2015.

. Tratado Político. Tradução Diogo Pires Aurélio. São Paulo: Martins Fontes, 2009.

(SPINOZA, B.). Traité politique. Troduction, notes, glossaires, index et bibliographie par Charles Ramond. Paris: Presses Universitaires de France, 2005.

. (SPINOZA, B.). Traité théologico-politique. Texte établi par Fokke Akkerman; Traduction et notes par Jacqueline Lagrée et Pierre-François Moreau. Paris: Presses Universitaires de France, 2012, 2e édition.

. Tratado Teológico-político. Tradução Diogo Pires Aurélio. São Paulo: Martins Fontes, 2003. 
GAFFIOT. F. Le grand Gaffiot. Diccionnaire latin-français. Revue et augmentée sous la direction de Pierre Flobert. Paris: Hachette-Livre, 2000, Troisième édition.

GALILEI, G. Ciência e fé. Cartas de Galileu sobre o acordo do sistema copernicano com a Bíblia. $2^{a}$ edição revista e ampliada. Nascimento, C. A. R. (org. e trad.). São Paulo: Editora UNESP, 2009.

GINZBURG, C. O queijo e os vermes. O cotidiano e as ideias de um moleiro perseguido pela Inquisição. São Paulo: Companhia das Letras, 2006.

HANSEN, J. A. A sátira e o engenho: Gregório de Matos e a Bahia do século XVII. São Paulo: Ateliê Editorial; Campinas: Editora da Unicamp , 2004.

JESUS, P. B. M. Sobre a elaboração de uma ciência das paixões em Descartes, Hobbes e Espinosa. Dissertação (Mestrado em Filosofia). Faculdade de Filosofia, Letras e Ciências Humanas. Universidade de São Paulo, 2015.

JOUANNA, J. Greek medicine from Hippocrates to Galen: selected papers by Jacques Jouanna; edited with a preface by Philip van der Eijk, translated by Neil Allies. Leiden; Boston: Brill, 2012.

KEPLER, J. Harmonies of the World. Translated by Charles Glenn Wallis, London, Toronto : Enciclopædia Britannica, 1952. (Great Books of the Western World, vol. 16).

KIRSTE, S.; WALTHER, M. "Political Philosophy as Theory of Practice (Chapter 1: Introduction)". In: BARTUCHAT, W., KIRSTE, S., WALTHER, M. (ed.). Naturalism and Democracy. A Commentary on Spinoza's Political Treatise in the Context of His System. Translated by James Fontini. Leiden; Boston: Brill, 2019, p. 11-16.

MAQUIAVEL, N. Discursos sobre a primeira década de Tito Lívio. Tradução MF. São Paulo : Martins Fontes, 2007.

. O Príncipe. Tradução Maria Júlia Goldwasser. São Paulo: Martins Fontes, 2001.

MARCOCCI, G. A consciência de um império. Portugal e o seu mundo (sécs. XVI-XVII). Coimbra: Imprensa da Universidade de Coimbra, 2012.

MATHERON, A. Études sur Spinoza et les philosophies de l'âge classique. Lyon: ENS Éditions, 2011.

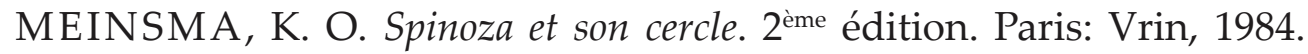

MORFINO, V. Le temps et l'occasion. La rencontre Spinoza-Machiavel. Paris: Classiques Garnier, 2012.

MUHANA, A. (ed.). Os Autos do Processo de Vieira na Inquisição, 1600-1668. Edição, transcrição, glossário e notas de Adma Muhana. São Paulo: EDUSP, 2008.

NEGRI, A. The Savage Anomaly. The power of Spinoza's metaphysics and politics. Translation by Michael Hardt. Minneapolis: University of Minnesota Press, 1991.

MULIER, E. H. "A controversial republican: Dutch views of Machiavelli in the seventeenth and eighteenth centuries". In: Bock, G; Skinner, Q.; Viroli, M. (ed.). Machiavelli and republicanism. Cambridge: Cambridge University Press, 1990, p. 247-64. 
ROSENTHAL, M. A. "Spinoza's political phisosophy". In: DELLA ROCCA, M. (ed.). The Oxford Handbook of Spinoza. New York: Oxford University Press, 2018, p. 408-33.

SANTIAGO, H. Geometria do instituído. Estudo sobre a gramática hebraica espinosana. Fortaleza: EDUECE, 2014.

"O filósofo espinosano precisa criar valores?". Trans/Form/Ação. São Paulo, 30(1), 2007, p. 127-49.

TOSEL, A. Du matérialisme de Spinoza. Paris: Éditions Kimé, 1994.

VARDOULAKIS, D. “Spinoza now: an introduction”. In: (ed.) Spinoza now. Minneapolis: The University of Minnesota, 2011, p. xi-xxvii.

VISENTIN, S. El movimiento de la democracia. Antropología y política em Spinoza. Tradución de Augustín Volco. Córdoba: Encunetro Grupo Editorial, 2011.

ZERON, C. A. R. M. Linha de fé. A Companhia de Jesus e a escravidão no processo de formação da sociedade colonial (Brasil, séculos XVI e XVII). São Paulo: Edusp, 2011.

Endereço do Autor:

Rua dos Pinheiros, no 563 - Apto. 3

Pinheiros

05422-011 São Paulo - SP

mdsf.antonio@gmail.com 